\title{
Secondary organic aerosol yields of 12-carbon alkanes
}

\author{
C. L. Loza ${ }^{1}$, J. S. Craven ${ }^{1}$, L. D. Yee ${ }^{2}$, M. M. Coggon ${ }^{1}$, R. H. Schwantes ${ }^{2}$, M. Shiraiwa ${ }^{1,3}$, X. Zhang ${ }^{2}$, K. A. Schilling ${ }^{1}$,

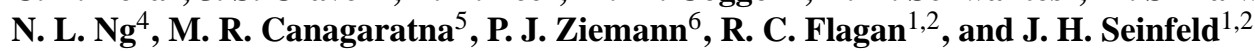 \\ ${ }^{1}$ Division of Chemistry and Chemical Engineering, California Institute of Technology, Pasadena, CA, USA \\ ${ }^{2}$ Division of Engineering and Applied Science, California Institute of Technology, Pasadena, CA, USA \\ ${ }^{3}$ Multiphase Chemistry Department, Max Planck Institute for Chemistry, Mainz, Germany \\ ${ }^{4}$ School of Chemical and Biomolecular Engineering and School of Earth and Atmospheric Sciences, Georgia Institute of \\ Technology, Atlanta, GA, USA \\ ${ }^{5}$ Aerodyne Research, Inc., Billerica, MA, USA \\ ${ }^{6}$ Air Pollution Research Center, Department of Environmental Sciences, and Environmental Toxicology Graduate Program, \\ University of California, Riverside, CA, USA
}

Correspondence to: J. H. Seinfeld (seinfeld@caltech.edu)

Received: 29 June 2013 - Published in Atmos. Chem. Phys. Discuss.: 7 August 2013

Revised: 13 December 2013 - Accepted: 23 December 2013 - Published: 7 February 2014

\begin{abstract}
Secondary organic aerosol (SOA) yields were measured for cyclododecane, hexylcyclohexane, $n$-dodecane, and 2-methylundecane under high- $\mathrm{NO}_{\mathrm{x}}$ conditions, in which alkyl proxy radicals $\left(\mathrm{RO}_{2}\right)$ react primarily with $\mathrm{NO}$, and under low- $\mathrm{NO}_{\mathrm{x}}$ conditions, in which $\mathrm{RO}_{2}$ reacts primarily with $\mathrm{HO}_{2}$. Experiments were run until $95-100 \%$ of the initial alkane had reacted. Particle wall loss was evaluated as two limiting cases using a new approach that requires only suspended particle number-size distribution data and accounts for size-dependent particle wall losses and condensation. SOA yield differed by a factor of 2 between the two limiting cases, but the same trends among alkane precursors were observed for both limiting cases. Vapor-phase wall losses were addressed through a modeling study and increased SOA yield uncertainty by approximately $30 \%$. SOA yields were highest from cyclododecane under both $\mathrm{NO}_{\mathrm{x}}$ conditions. SOA yields ranged from $3.3 \%$ (dodecane, low- $\mathrm{NO}_{\mathrm{x}}$ conditions) to 160 $\%$ (cyclododecane, high- $\mathrm{NO}_{\mathrm{x}}$ conditions). Under high- $\mathrm{NO}_{\mathrm{x}}$ conditions, SOA yields increased from 2-methylundecane $<$ dodecane $\sim$ hexylcyclohexane $<$ cyclododecane, consistent with previous studies. Under low- $\mathrm{NO}_{\mathrm{x}}$ conditions, SOA yields increased from 2-methylundecane $\sim$ dodecane $<$ hexylcyclohexane $<$ cyclododecane. The presence of cyclization in the parent alkane structure increased SOA yields, whereas the presence of branch points decreased SOA yields due to increased vapor-phase fragmentation.
\end{abstract}

Vapor-phase fragmentation was found to be more prevalent under high- $\mathrm{NO}_{\mathrm{x}}$ conditions than under low- $\mathrm{NO}_{\mathrm{x}}$ conditions. For different initial mixing ratios of the same alkane and same $\mathrm{NO}_{\mathrm{x}}$ conditions, SOA yield did not correlate with SOA mass throughout SOA growth, suggesting kinetically limited SOA growth for these systems.

\section{Introduction}

Alkanes are emitted from combustion sources and can comprise up to $90 \%$ of anthropogenic emissions in urban areas (Rogge et al., 1993; Fraser et al., 1997; Schauer et al., 1999, 2002) and $67.5 \%, 56.8 \%$, and $82.8 \%$ of the mass of diesel fuel, liquid gasoline, and non-tailpipe gasoline sources, respectively (Gentner et al., 2012). Upon atmospheric oxidation by $\mathrm{OH}$ and $\mathrm{NO}_{3}$ radicals, alkanes form lower-volatility products that can condense as secondary organic aerosol (SOA). Ambient lifetimes against reaction with $\mathrm{OH}$ range, for example, from 0.5 days for $n$-hexadecane to 1.4 days for $n$-octane (Atkinson and Arey, 2003; Seinfeld and Pandis, 2006), allowing for the transport of alkanes from urban to rural areas.

SOA formation under high- $\mathrm{NO}_{\mathrm{x}}$ conditions, in which alkyl proxy radicals $\left(\mathrm{RO}_{2}\right)$ react primarily with $\mathrm{NO}$, has received much attention. Lim and Ziemann (2005, 2009a, c) developed a mechanism for linear, branched, and cyclic alkane 
oxidation that includes the formation of multi-generation oxidation products. SOA yields, defined as mass of SOA formed divided by mass of alkane reacted, have been measured in the laboratory for $\mathrm{C}_{7}-\mathrm{C}_{25}$ alkanes with linear, branched, and cyclic structures (Lim and Ziemann, 2005, 2009b; Presto et al., 2010; Tkacik et al., 2012). In these studies, SOA yields are reported after $50-85 \%$ of the alkane had reacted and may not represent the maximum possible yield. Generally, SOA yield was found to increase with increasing carbon number or the presence of a cyclic structure and decrease with branching of the carbon chain.

SOA formation under low- $\mathrm{NO}_{\mathrm{x}}$ conditions, in which $\mathrm{RO}_{2}$ reacts primarily with $\mathrm{HO}_{2}$, has received less attention. Yee et al. $(2012,2013)$ developed an oxidation mechanism for $n$ dodecane and extended it to cyclic and branched compounds. Yee et al. $(2012,2013)$ also identified multiple generations of alkane oxidation products, and Craven et al. (2012) used positive matrix factorization to demonstrate continuous evolution of the chemical composition of SOA generated during $36 \mathrm{~h}$ of low- $\mathrm{NO}_{\mathrm{x}}$ dodecane photooxidation. SOA yields for select linear and cyclic structures have been measured, and the same trends for carbon number and presence of a cyclic structure were observed under low- $\mathrm{NO}_{\mathrm{x}}$ conditions as under high- $\mathrm{NO}_{\mathrm{x}}$ conditions (Lambe et al., 2012).

Here we report SOA yields from 12-carbon alkanes with linear, cyclic, and branched structures under both high- and low- $\mathrm{NO}_{\mathrm{x}}$ conditions. In each experiment, $95-100 \%$ of the alkane, a greater percentage than those achieved in previous chamber studies, was oxidized to study the contribution of multi-generation products to SOA yield. Additionally, multiple alkane mixing ratios were used to assess the effect of precursor mixing ratio on gas-particle partitioning.

\section{Materials and methods}

\subsection{Experimental setup}

Low- $\mathrm{NO}_{\mathrm{x}}$ experiments were conducted in the Caltech dual $28 \mathrm{~m}^{3}$ Teflon chambers, details of which are given elsewhere (Cocker et al., 2001; Keywood et al., 2004). High- $\mathrm{NO}_{\mathrm{x}}$ experiments were conducted in the Caltech dual $24 \mathrm{~m}^{3}$ Teflon chambers, located in a new facility that replaced the $28 \mathrm{~m}^{3}$ chamber facility. Most components of the old facility, including instrumentation, were moved to the new laboratory, which provides precise temperature control of the chambers $\left( \pm 1^{\circ} \mathrm{C}\right)$ and flushing at a rate approximately 3 times faster than that in the $28 \mathrm{~m}^{3}$ chamber facility. The difference in chamber volume is not expected to influence the experiment outcomes. Before each experiment, the chambers were flushed with dried, purified air for $>24 \mathrm{~h}$, until the particle number concentration was $<50 \mathrm{~cm}^{-3}$ and the volume concentration was $<0.1 \mu \mathrm{m}^{3} \mathrm{~cm}^{-3}$. First, hydrogen peroxide $\left(\mathrm{H}_{2} \mathrm{O}_{2}, 50 \%\right.$ wt., Sigma Aldrich) was added to the chamber by flowing purified air over a measured volume of $\mathrm{H}_{2} \mathrm{O}_{2}$ in a glass bulb maintained at $30-35^{\circ} \mathrm{C}$. Volumes of 70 and $280 \mu \mathrm{L}$ were used for high- $\mathrm{NO}_{\mathrm{x}}$ and low- $\mathrm{NO}_{\mathrm{x}}$, experiments, respectively. Next, seed particles were injected by atomizing a $0.015 \mathrm{M}$ aqueous ammonium sulfate solution. $n$-Dodecane (Sigma Aldrich, 99+\% purity), 2-methylundecane (TCI, America, $>98 \%$ purity), or hexylcyclohexane (TCI, America, $>98 \%$ purity) was introduced into the chamber by evaporating a known alkane liquid volume with $5 \mathrm{~L} \mathrm{~min}^{-1}$ of purified air. Cyclododecane (TCI, America, $>99 \%$ purity) was introduced into the chamber by evaporating a known cyclododecane mass with $5 \mathrm{~L} \mathrm{~min}^{-1}$ of purified air. During each injection, the glass bulb containing the liquid or solid alkane was heated slightly to facilitate evaporation. For high- $\mathrm{NO}_{\mathrm{x}}$ experiments, approximately $100 \mathrm{ppbv} \mathrm{NO}$ was then added to the chamber from a $510 \mathrm{ppmv} \mathrm{NO}$ in $\mathrm{N}_{2}$ cylinder (Air Liquide). The chamber contents were allowed to mix for $1 \mathrm{~h}$ before beginning irradiation with $350 \mathrm{~nm}$-centered UV broadband lamps ( $40 \mathrm{~W}$ Sylvania 350BL). Different light intensities were used for low- and high- $\mathrm{NO}_{\mathrm{x}}$ experiments corresponding to $j_{\mathrm{NO}_{2}} \sim 4 \times 10^{-3} \mathrm{~s}^{-1}$ and $\sim 6 \times 10^{-3} \mathrm{~s}^{-1}$, respectively. To maintain high- $\mathrm{NO}_{\mathrm{x}}$ conditions, $20 \mathrm{sccm}$ of 510 ppmv NO was continuously injected into the chamber during the irradiation period. This additional $\sim 21 \mathrm{~L}$ of $\mathrm{N}_{2}$ has a negligible effect on chamber volume. The chamber contents were irradiated for $18 \mathrm{~h}$ and $30-36 \mathrm{~h}$ for high- and low$\mathrm{NO}_{\mathrm{x}}$ experiments, respectively, to achieve similar $\mathrm{OH}$ exposures in all experiments.

A suite of instruments was used to study the evolution of the gas and particle phases. Alkane mixing ratios were measured using a gas chromatograph with flame ionization detector (GC/FID, Agilent $6890 \mathrm{~N}$ ), equipped with a HP-5 column $(15 \mathrm{~m} \times 0.53 \mathrm{~mm}$ ID $\times 1.5 \mu \mathrm{m}$ thickness, Agilent $)$. Samples for injection into the GC/FID were taken by drawing $1.3 \mathrm{~L}$ of chamber air at a flow rate of $0.13 \mathrm{~L} \mathrm{~min}^{-3}$ through a glass tube packed with Tenax TA resin. The glass tube was subsequently desorbed for $10 \mathrm{~min}$ in the inlet of the GC/FID at 260 and $275^{\circ} \mathrm{C}$ for low- and high- $\mathrm{NO}_{\mathrm{x}}$ experiments, respectively, onto the column, held at $30^{\circ} \mathrm{C}$. After $15 \mathrm{~min}$, the oven temperature was ramped at $10^{\circ} \mathrm{Cmin}^{-1}$ to $280^{\circ} \mathrm{C}$ and held at that temperature for $5 \mathrm{~min}$. The mass response of the detector was calibrated for each alkane using Tenax tubes spiked with standard solutions and analyzed using the same method as the sample tubes. Relative humidity $(\mathrm{RH})$, temperature, NO, $\mathrm{NO}_{\mathrm{x}}$, and $\mathrm{O}_{3}$ were continuously monitored. Alkane oxidation products were detected using a custom-modified Varian 1200 triple-quadrupole chemical ionization mass spectrometer (CIMS). Details of operation can be found elsewhere (Crounse et al., 2006; Paulot et al., 2009; Yee et al., 2012, 2013). The CIMS was operated in negative mode in which $\mathrm{CF}_{3} \mathrm{O}^{-}$is used as the reagent ion. $\mathrm{CF}_{3} \mathrm{O}^{-}$clusters with the analyte, $\mathrm{R}$, forming ions $\left[\mathrm{R} \cdot \mathrm{CF}_{3} \mathrm{O}\right]^{-}$at mass-to-charge ratio $(m / z)[\mathbf{M}+85]^{-}$, where $\mathbf{M}$ is the nominal weight of $\mathbf{R}$. For acidic species, the transfer product forms ions $[\mathrm{R} \cdot \mathrm{F}]^{-}$at $m / z$ $[\mathrm{M}+19]^{-}$. Some analytes can be seen in both the cluster and 
Table 1. SOA precursor and aerosol properties.

\begin{tabular}{|c|c|c|c|c|}
\hline Alkane & Structure & $\begin{array}{c}k_{\mathrm{OH}} \times 10^{12 \mathrm{a}} \\
\left(\mathrm{cm}^{3} \mathrm{~s}^{-1}\right)\end{array}$ & $\begin{array}{l}\mathrm{High}^{-\mathrm{NO}_{\mathrm{x}}} \\
\text { SOA density } \\
\quad\left(\mathrm{g} \mathrm{cm}^{-3}\right)\end{array}$ & $\begin{array}{l}\text { Low-NO } \\
\text { SOA density } \\
\left(\mathrm{g} \mathrm{cm}^{-3}\right)\end{array}$ \\
\hline$n$-Dodecane (Dod) & & $13.9^{\mathrm{c}}$ & $1.28 \pm 0.01$ & $1.12 \pm 0.03$ \\
\hline 2-Methylundecane (Mud) & & $13.1 \pm 0.7$ & $1.28 \pm 0.01$ & $1.12 \pm 0.03$ \\
\hline Hexylcyclohexane (Hch) & & $17.4 \pm 0.6$ & $1.29 \pm 0.01$ & $1.17 \pm 0.03$ \\
\hline Cyclododecane (Cdd) & & $14.7 \pm 0.4$ & $1.23 \pm 0.02$ & $1.28 \pm 0.03$ \\
\hline
\end{tabular}

transfer product forms. The signal at each $m / z$ represents the sum of signals from all isomers contributing to that $\mathrm{m} / \mathrm{z}$.

Aerosol size distribution and number concentration were measured continuously using a custom-built scanning mobility particle sizer consisting of a differential mobility analyzer (DMA, TSI, 3081) coupled to a condensation particle counter (CPC, TSI, 3010), henceforth referred to as the DMA. The DMA was operated in a closed-loop configuration with a recirculating sheath and excess flow of $2.67 \mathrm{Lmin}^{-1}$ and a $5.4: 1$ ratio of sheath to aerosol flow rates. The column voltage was scanned either from 10 to $1000 \mathrm{~V}$ over $100 \mathrm{~s}$ or 15 to $9850 \mathrm{~V}$ over $45 \mathrm{~s}$.

Real-time particle mass spectra were collected continuously by an Aerodyne high-resolution time-of-flight aerosol mass spectrometer (AMS, DeCarlo et al., 2006; Canagaratna et al., 2007). The AMS switched between the higher resolution, lower sensitivity "W-mode" and the lower resolution, higher sensitivity "V-mode". AMS data were processed using the ToF-AMS Unit Resolution Analysis Toolkit, "SQUIRREL" (http://cires.colorado.edu/jimenez-group/ ToFAMSResources/ToFSoftware/index.html), in Igor Pro Version 6.31 (Wavemetrics, Lake Oswego, OR). "V-mode" data were analyzed using fragmentation table to separate sulfate, ammonium, and organic spectra and to time-trace specific mass-to-charge ratios (Allan et al., 2004). "V-mode" and "W-mode" data were analyzed using the high-resolution spectra toolbox known as PIKA (Peak Integration by Key Analysis) to determine the chemical formulas contributing to distinct $m / z$ ratios (DeCarlo et al., 2006). Organic ions up to $m / z 305$ were used to calculate elemental ratios. Craven et al. (2012) proposed formulas for organic ions with $m / z>100$ observed for low- $\mathrm{NO}_{\mathrm{x}}$ dodecane photooxidation SOA based on hypothesized fragmentation of products formed in the dodecane photooxidation mechanism (Yee et al., 2012). Similar analysis was applied to identify organic ions with $m / z>100$ for SOA from all 4 alkanes investigated here under both low- and high- $\mathrm{NO}_{\mathrm{x}}$ conditions. Organic ions $\mathrm{CO}^{+}$and $\mathrm{C}_{2} \mathrm{H}_{4}^{+}$were not fit in "V-mode" due to the large interference from the $\mathrm{N}_{2}^{+}$peak, and their signals were estimated from those of particle-phase $\mathrm{CO}_{2}^{+}$and $\mathrm{C}_{2} \mathrm{H}_{3}^{+}$, respectively, using correlations determined from "W-mode" data, which has better resolution of the $\mathrm{CO}^{+}, \mathrm{N}_{2}^{+}$, and $\mathrm{C}_{2} \mathrm{H}_{4}^{+}$ peaks. The ratio of particle-phase $\mathrm{CO}^{+}$to $\mathrm{CO}_{2}^{+}$varied by experiment between 0.45 and 3.5 , and a specific ratio was used for each experiment (see Table S1). The ratio of $\mathrm{C}_{2} \mathrm{H}_{4}^{+}$ to $\mathrm{C}_{2} \mathrm{H}_{3}^{+}$was found to be 0.47 for SOA from dodecane, 2-methylundecane, and hexylcyclohexane and 0.40 for SOA from cyclododecane under both $\mathrm{NO}_{\mathrm{x}}$ conditions. Additionally, the intensities of $\mathrm{H}_{2} \mathrm{O}^{+}, \mathrm{OH}^{+}$, and $\mathrm{O}^{+}$were calculated from particle-phase $\mathrm{CO}_{2}^{+}$(Aiken et al., 2008). AMS data reported in this work were collected using "V-mode" and averaged over $1 \mathrm{~h}$ or $30 \mathrm{~min}$ intervals for low- or high- $\mathrm{NO}_{\mathrm{x}}$ experiments, respectively.

Experimental $\mathrm{OH}$ concentrations were calculated from the measured alkane mixing ratio, the alkane concentration decay rate, estimated from the alkane mixing ratio fit to a differentiable function (typically, a 1- or 2-term exponential function), and the alkane $+\mathrm{OH}$ reaction rate constant. A literature $\mathrm{OH}$ reaction rate constant was available only for dodecane; rate constants for the other three alkanes were estimated from a relative rate experiment in which $10 \mathrm{ppbv}$ of each alkane was oxidized simultaneously under low- $\mathrm{NO}_{\mathrm{x}}$ conditions (Table 1). The measured rate constant for hexylcyclohexane is in good agreement with that calculated from structure-activity relationships (Kwok and Atkinson, 1995), $17.6 \times 10^{-12} \mathrm{~cm}^{3} \mathrm{molec}^{-1} \mathrm{~s}^{-1}$, and the measured rate constants for 2-methylundecane and cyclododecane are lower than those calculated from structure-activity relationships, 


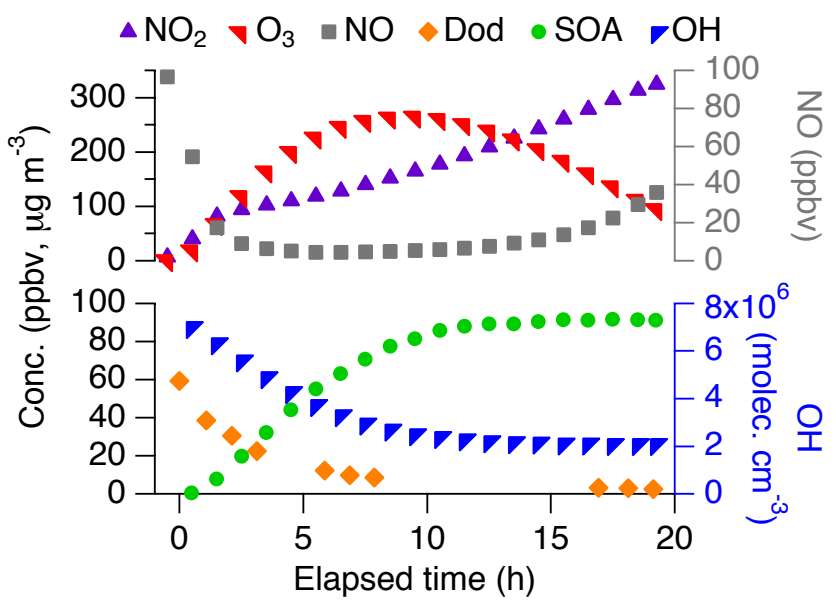

Fig. 1. Temporal trends of gas-phase species and SOA mass concentration during a typical high- $\mathrm{NO}_{\mathrm{x}}$ experiment. On the left axis, SOA mass concentration (lower limit) is reported in $\mu \mathrm{g} \mathrm{m}^{-3}$, and dodecane, $\mathrm{O}_{3}$, and $\mathrm{NO}_{2}$ mixing ratios are reported in ppbv. $\mathrm{NO}$ and $\mathrm{OH}$ concentrations are given on the right axis. $\mathrm{NO}_{2}, \mathrm{O}_{3}, \mathrm{NO}, \mathrm{SOA}$ mass, and $\mathrm{OH}$ concentrations are hourly averaged. Data are shown for the 57 ppbv dodecane experiment, DH2 (see Table 2). OH concentration was calculated from the dodecane decay.

$13.9 \times 10^{-12}$ and $17.0 \times 10^{-12} \mathrm{~cm}^{3} \mathrm{molec}^{-1} \mathrm{~s}^{-1}$, respectively. To calculate $\mathrm{OH}$ exposure, an interpolated $\mathrm{OH}$ concentration with a time resolution of $2-3 \mathrm{~min}$ is calculated from a fit to experimental data, as described previously, the alkane mixing ratio decay rate, and the alkane $+\mathrm{OH}$ reaction rate constant. The interpolated $\mathrm{OH}$ concentration is multiplied by the time between data points and summed to each time point to obtain $\mathrm{OH}$ exposure.

Photolysis of $\mathrm{H}_{2} \mathrm{O}_{2}$ under low- $\mathrm{NO}_{\mathrm{x}}$ conditions produced a constant $\mathrm{OH}$ radical concentration of (1-3) $\times 10^{6}$ molec $\mathrm{cm}^{-3}$. Under high- $\mathrm{NO}_{\mathrm{x}}$ conditions, $\mathrm{OH}$ radicals also were produced throughout the entire irradiation period, $18 \mathrm{~h}$, with initial concentrations of $(0.7-3) \times 10^{7} \mathrm{molec}^{-3}$ that decreased steadily to (1-5) $\times 10^{6} \mathrm{molec}^{-3}$ after $18 \mathrm{~h}$. In addition, reaction of $\mathrm{HO}_{2}$ radicals with $\mathrm{NO}$ produced $\mathrm{NO}_{2}$, which photolyzed to produce $\mathrm{O}_{3} \cdot \mathrm{O}_{3}$ mixing ratios peaked at $200-600 \mathrm{ppbv}$ approximately halfway through the experiment and then decreased as NO was continuously injected into the chamber. The variance in $\mathrm{O}_{3}$ mixing ratio is not expected to affect SOA formation mechanisms and is discussed below. Typical vapor mixing ratios and $\mathrm{SOA}$ growth for a high- $\mathrm{NO}_{\mathrm{x}}$ experiment (59 ppbv dodecane) are shown in Fig. 1.

Three oxidants, $\mathrm{OH}, \mathrm{O}_{3}$, and $\mathrm{NO}_{3}$, were produced under high- $\mathrm{NO}_{\mathrm{x}}$ conditions. All oxidant concentrations varied during the experiment due to the continuous addition of NO. While $\mathrm{O}_{3}$ is not expected to react with most alkane photooxidation products, it can react with dihydrofurans, which also react with $\mathrm{OH}$ and $\mathrm{NO}_{3}$. Variation in $\mathrm{O}_{3}$ mixing ratios amongst the experiments could influence SOA yields by af- fecting the fate of dihydrofurans. In the present experiments, the ratios of dihydrofuran sinks were determined by comparing the lifetimes for dihydrofuran against reaction with $\mathrm{OH}$, $\mathrm{O}_{3}$, and $\mathrm{NO}_{3}$ at experimental conditions. Jordan et al. (2008) estimated $\mathrm{C}_{12}$ dihydrofuran $+\mathrm{OH}$ rate constants as approximately $2.4 \times 10^{-13} \mathrm{~cm}^{3} \mathrm{molec}^{-1} \mathrm{~s}^{-1}$. The rate constants for $\mathrm{C}_{12}$ dihydrofuran $+\mathrm{O}_{3}$ and $\mathrm{C}_{12}$ dihydrofuran $+\mathrm{NO}_{3}$ were taken as $3.49 \times 10^{-15}$ and $1.68 \times 10^{-10} \mathrm{~cm}^{3} \mathrm{molec}^{-1} \mathrm{~s}^{-1}$, respectively, as measured for 4,5-dihydro-2-methylfuran by Martin et al. (2002). $\mathrm{O}_{3}$ mixing ratios were measured directly, $\mathrm{OH}$ concentrations were calculated from the alkane mixing ratio decay, and $\mathrm{NO}_{3}$ concentrations were estimated from a photochemical model. The lifetime for dihydrofuran against reaction with $\mathrm{O}_{3}$ was calculated to be at least an order of magnitude less than that against reaction with $\mathrm{OH}$ for all experimental conditions, and the variation in $\mathrm{O}_{3}$ mixing ratios amongst the experiments had little effect on the fate of dihydrofurans. For the highest estimated $\mathrm{NO}_{3}$ concentration $\left(1 \times 10^{7} \mathrm{molec} \mathrm{cm}^{-3}\right)$, the lifetime for dihydrofuran against reaction with $\mathrm{NO}_{3}$ was comparable to that against reaction with $\mathrm{O}_{3}$, and at the lowest estimated concentration, the lifetime for dihydrofuran against reaction with $\mathrm{NO}_{3}$ was an order of magnitude larger than that against reaction $\mathrm{OH}$. In an urban area such as Mexico City with maximum $\mathrm{OH}, \mathrm{O}_{3}$, and $\mathrm{NO}_{3}$ (daytime) concentrations of $4.6 \times$ $10^{6},(0.74-2.0) \times 10^{12}$, and $2.4 \times 10^{7} \mathrm{molec} \mathrm{cm}^{-3}$, respectively (Molina et al., 2010; Stephens et al., 2008; Volkamer et al., 2010), the estimated lifetimes for dihydrofuran against reaction with these compounds are $15 \mathrm{~min}, 2.4-6.4 \mathrm{~min}$, and $4.1 \mathrm{~min}$, respectively. The conditions in the present experiments produce atmospherically relevant ratios of dihydrofuran sinks. Additionally, $\mathrm{NO}_{3}$ was not a significant sink of either the parent alkane or $\mathrm{RO}_{2}$ radicals even at the largest estimated $\mathrm{NO}_{3}$ mixing ratio.

\subsection{SOA yield calculations}

Particles deposited to the chamber walls are accounted for when calculating the mass concentration of organic aerosol formed. Particle wall-loss corrections were made using the two limiting assumptions of gas-particle partitioning (Weitkamp et al., 2007; Hildebrandt et al., 2009; Loza et al., 2012). In one limit, no suspended vapors are assumed to condense on deposited particles. This limit is termed the lower limit because it represents the smallest possible SOA mass formed during growth. In the other limit, deposited particles are assumed to interact with suspended vapors to the same extent as suspended particles. This limit is termed the upper limit because it represents the largest possible SOA mass formed during growth. A new approach to calculate both upper and lower limit wall loss solely from suspended particle number-size distribution data is described in Appendix A. This approach is an extension of the Aerosol Parameterization Estimation model (Pierce et al., 2008) to calculate both limits to particle wall-loss corrections. Total particle volume 
concentration was calculated from the wall-loss corrected number-size distributions. To obtain SOA mass concentration, the seed particle volume concentration was subtracted from the total particle volume concentration, and the resulting organic particle volume concentration was multiplied by the SOA density, calculated from DMA and AMS data from a separate experiment (see Table 1).

SOA yield, $Y$, was calculated for both upper and lower limit SOA mass concentrations, $\Delta M_{\mathrm{o}}\left(\mu \mathrm{g} \mathrm{m}^{-3}\right)$, using

$Y=\frac{\Delta M_{\mathrm{o}}}{\Delta \mathrm{HC}}$

where $\Delta \mathrm{HC}\left(\mu \mathrm{g} \mathrm{m}^{-3}\right)$ is the mass concentration of alkane reacted.

In addition to particle-phase wall losses, vapor-phase wall losses of 12-carbon alcohols and ketones have been observed in laboratory chambers (Matsunaga and Ziemann, 2010). If vapors condense on chamber walls instead of on particles, then SOA yields will be underestimated. Vapor wall losses were not taken into account for the yields presented here; the effect of vapor wall losses on SOA yields is discussed in Appendix B.

\section{Results and discussion}

For most SOA precursors, a larger initial hydrocarbon mixing ratio results in a larger source of semivolatile oxidation products, assuming that reactions occur at the same temperature and oxidizing conditions and that the vapor-phase product distributions do not vary over the range of initial hydrocarbon mixing ratios considered. The presence of more condensible products facilitates partitioning of semivolatile product species to the particle phase, leading to increased yields relative to lower mixing ratio experiments. Oxidant exposure also affects SOA yield. SOA yield increases with increasing oxidant exposure as the hydrocarbon reacts forming multiple generations of semivolatile products; however, with ever-increasing oxidation, fragmentation reactions will begin to dominate over functionalization reactions, producing volatile products that do not condense or evaporate from the condensed phase and decreasing SOA yield.

\subsection{High-NO ${ }_{x}$ SOA yield measurements}

Conditions for high- $\mathrm{NO}_{\mathrm{x}}$ experiments are given in Table 2. The reported $\Delta M_{\mathrm{o}}$ and yield correspond to approximately $18 \mathrm{~h}$ of irradiation and an $\mathrm{OH}$ exposure of $(6-12) \times 10^{7} \mathrm{molec}^{-3} \mathrm{~h}$. By this point, at least $95 \%$ of the initial hydrocarbon had reacted. SOA growth occurred continuously as the alkane reacted. Figure 2a shows the SOA yield after approximately $18 \mathrm{~h}$ of irradiation as a function of hydrocarbon concentration reacted. The top and bottom of each line correspond to the upper and lower limits to the particle wall-loss correction, respectively. Experiments were
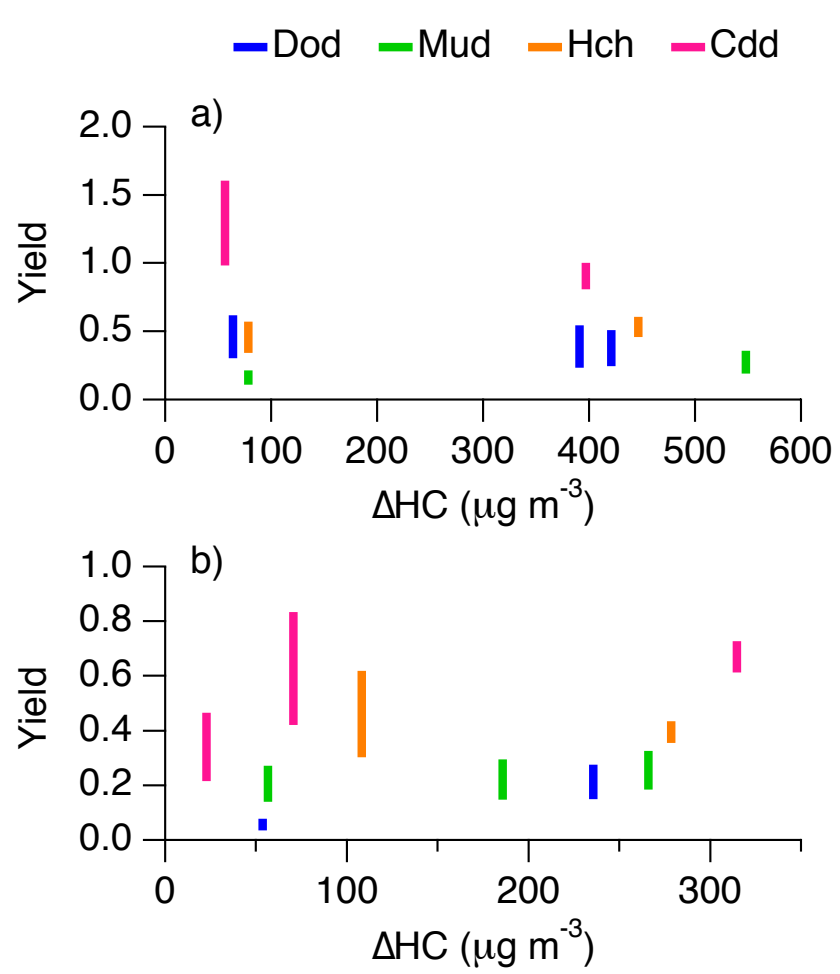

Fig. 2. SOA yield at $95-100 \%$ of initial hydrocarbon reacted under (a) high- and (b) low- $\mathrm{NO}_{\mathrm{x}}$ conditions. Each line shows the range between the lower limit (deposited particles do not undergo gasparticle partitioning) and upper limit (gas-particle partitioning to deposited particles is the same as that to suspended particles) SOA yields for an experiment.

run with approximately $10 \mathrm{ppbv}\left(100 \mu \mathrm{g} \mathrm{m}^{-3}\right)$ or $60-80 \mathrm{ppbv}$ (400-550 $\mu \mathrm{g} \mathrm{m}^{-3}$ ) initial alkane mixing ratio. In both initial alkane concentration regimes, cyclododecane produced the largest yields, while the smallest yields were observed for 2-methylundecane. Dodecane and hexylcyclohexane yields were similar. These results are consistent with the relationship between alkane structure and SOA yield observed by Lim and Ziemann (2009b) and Tkacik et al. (2012). When comparing the yields for each compound between the two initial hydrocarbon concentration regimes, no clear patterns emerge. For 2-methylundecane and hexylcyclohexane, the yield increases as initial alkane concentration increases. For dodecane and cyclododecane, the yield decreases as initial alkane concentration increases. This behavior will be discussed further in Sect. 3.4.

For cyclododecane and hexylcyclohexane, a large difference between upper and lower limit yields is observed in Fig. 2 for experiments with $\Delta \mathrm{HC}<100 \mu \mathrm{g} \mathrm{m}^{-3}$. These experiments had approximately $10 \mathrm{ppbv}$ initial alkane. For experiments shown in Fig. 2 with $\Delta \mathrm{HC}>100 \mu \mathrm{g} \mathrm{m}^{-3}$, those with 60-80 ppbv initial alkane, SOA growth began soon after the onset of irradiation, increasing the suspended particle number-size distribution peak diameter to $250-350 \mathrm{~nm}$. 
Table 2. High- $\mathrm{NO}_{\mathrm{x}}$ experimental details.

\begin{tabular}{|c|c|c|c|c|c|c|c|c|}
\hline Expt. $^{a}$ & Alkane & $\begin{array}{r}\text { Seed vol. } \\
\left(\mu \mathrm{m}^{3} \mathrm{~cm}^{-3}\right)\end{array}$ & $\begin{array}{l}\mathrm{NO}_{\mathrm{o}}{ }^{\mathrm{b}} \\
(\mathrm{ppbv})\end{array}$ & $\begin{array}{c}\mathrm{NO}_{2, \mathrm{o}} \mathrm{b} \\
(\mathrm{ppbv})\end{array}$ & $\begin{array}{r}\mathrm{HC}_{\mathrm{o}} \\
(\mathrm{ppbv})\end{array}$ & $\begin{array}{r}\Delta \mathrm{HC} \\
(\mathrm{ppbv})\end{array}$ & $\begin{array}{r}\Delta M_{\mathrm{o}}^{\mathrm{c}} \\
\left(\mu \mathrm{g} \mathrm{m}^{-3}\right)\end{array}$ & $\begin{array}{l}\text { Yield }^{\mathrm{c}} \\
\text { (frac.) }\end{array}$ \\
\hline MH1 & Mud & $31.7 \pm 9.5$ & $94.1 \pm 0.5$ & $6.6 \pm 0.2$ & $11.6 \pm 0.4$ & 11.6 & $8.5-17$ & $0.11-0.21$ \\
\hline MH2 & Mud & $41.6 \pm 12.5$ & $97.7 \pm 0.5$ & $5.8 \pm 0.2$ & $79.6 \pm 2.5$ & 79.1 & $100-200$ & $0.19-0.38$ \\
\hline DH1 & Dod & $30.9 \pm 9.3$ & $93.8 \pm 0.5$ & $6.3 \pm 0.2$ & $9.7 \pm 0.3$ & 9.2 & $19-40$ & $0.30-0.62$ \\
\hline $\mathrm{DH} 2$ & Dod & $26.1 \pm 7.8$ & $96.8 \pm 0.5$ & $7.1 \pm 0.2$ & $59.2 \pm 1.9$ & 56.8 & $91-210$ & $0.23-0.54$ \\
\hline DH3 & Dod & $30.4 \pm 9.1$ & $96.5 \pm 0.5$ & $6.1 \pm 0.2$ & $63.6 \pm 2.0$ & 61.2 & $100-210$ & $0.22-0.51$ \\
\hline HH1 & Hch & $34.1 \pm 10.2$ & $101 \pm 0.5$ & $2.6 \pm 0.2$ & $11.5 \pm 0.4$ & 11.5 & $27-45$ & $0.34-0.57$ \\
\hline $\mathrm{HH} 2$ & Hch & $40.0 \pm 12.0$ & $95.4 \pm 0.5$ & $2.9 \pm 0.2$ & $65.0 \pm 2.1$ & 64.9 & $210-270$ & $0.46-0.61$ \\
\hline $\mathrm{CH} 1$ & Cdd & $38.7 \pm 11.6$ & $95.6 \pm 0.5$ & $6.8 \pm 0.2$ & $8.5 \pm 0.3$ & 8.5 & $56-91$ & $0.98-1.6$ \\
\hline $\mathrm{CH} 2$ & Cdd & $37.7 \pm 11.3$ & $93.4 \pm 0.5$ & $7.9 \pm 0.2$ & $61.0 \pm 2.0$ & 58.6 & $320-400$ & $0.80-1.0$ \\
\hline
\end{tabular}

${ }^{a}$ The first letter of each experiment identifier refers to the alkane, and the second letter refers to high- $(\mathrm{H})$ or low- $(\mathrm{L}) \mathrm{NO}_{\mathrm{x}}$ conditions.

$\mathrm{b}$ One standard deviation is reported, as measured by the instrument manufacturer.

c The range of values listed correspond to the two limiting assumptions for suspended vapor-deposited particle gas-particle partitioning. The smaller and larger values correspond to the upper and lower partitioning limits, respectively.

During the experiments with $\sim 10 \mathrm{ppbv}$ initial alkane, SOA growth did not begin immediately, and the suspended particle number-size distribution peak diameter remained below $200 \mathrm{~nm}$ for most of the experiment. The temporal trend of suspended particle number-size distribution peak diameter for the high- $\mathrm{NO}_{\mathrm{x}}$ cyclododecane experiments is shown in Fig. S1. In the Caltech chambers, particle wall-loss rate constants are lowest for $200-300 \mathrm{~nm}$ particles (Fig. S1, right panel). Typical seed particle number-size distribution peak diameters are $40-60 \mathrm{~nm}$. Because particle growth is slower in $\sim 10 \mathrm{ppbv}$ initial alkane experiments and particles remain at a smaller diameter for longer times, more particles are lost to the wall before and during SOA growth in $\sim 10 \mathrm{ppbv}$ initial alkane experiments than in those with $60-80$ ppbv initial alkane, owing to the size-dependence of particle wall loss. Therefore, a large difference between lower and upper limit yields is observed for the $\sim 10 \mathrm{ppbv}$ initial alkane experiments. The difference between upper and lower limit yields for dodecane and 2-methylundecane is similar for all $\Delta \mathrm{HC}$. Less overall SOA growth is observed for dodecane and 2methylundecane; as a result, less difference is observed between the lower and upper limit yields.

SOA yields from cyclododecane were close to or greater than 1 depending on the wall-loss correction method used. SOA yields can be $>1$ if most of the functionalized oxidation products generated from a non-functionalized parent hydrocarbon condense to form SOA. SOA yields $>1$ have been observed previously from longifolene photooxidation under high- $\mathrm{NO}_{\mathrm{x}}$ conditions ( $\mathrm{Ng}$ et al., 2007a). To determine if the SOA mass produced violated mass conservation, an estimation of maximum potential SOA mass concentration was calculated assuming that all oxidation products formed from the reacted cyclododecane condensed. For the estimation, the average SOA molecular weight was calculated from the oxygen-to-carbon $(\mathrm{O}: \mathrm{C})$, hydrogen-to-carbon $(\mathrm{H}: \mathrm{C})$, and nitrogen-to-carbon $(\mathrm{N}: \mathrm{C})$ ratios measured by the AMS, as- suming that condensed species retain 12 carbon atoms. Note that ions $\mathrm{NO}^{+}$and $\mathrm{NO}_{2}^{+}$are included in these calculations and will be discussed further in Sect. 3.4. To calculate the maximum potential SOA mass concentration, the molar concentration of cyclododecane reacted is multiplied by the average SOA molecular weight. This SOA mass concentration is then compared to the observed SOA mass concentration. For experiment $\mathrm{CH} 1$ (cyclododecane), the maximum potential SOA formed was $84 \mu \mathrm{g} \mathrm{m}^{-3}$, which is greater than the lower wall-loss limit $\Delta M_{\mathrm{o}}$ but less than the upper wall-loss limit $\Delta M_{\mathrm{o}}$. For experiment $\mathrm{CH} 2$ (cyclododecane), the maximum potential SOA formed was $519 \mu \mathrm{g} \mathrm{m}^{-3}$, which is greater than both the lower and upper bound limit $\Delta M_{\mathrm{o}}$. All observed cyclododecane yields except for the upper wall-loss limit yield for $\mathrm{CH} 1$ do not violate mass conservation. It is likely that uncertainties in deposited particle growth rates calculated in the upper limit wall-loss correction method (see Appendix A) cause the upper limit yield for $\mathrm{CH} 1$ to be overestimated.

Previous studies exist of SOA yields under high- $\mathrm{NO}_{\mathrm{x}}$ conditions for dodecane, 2-methylundecane, and cyclododecane. Lim and Ziemann (2009b) measured SOA yields for all three compounds with initial alkane mixing ratios of approximately $1 \mathrm{ppmv}$, of which $76-83 \%$ was oxidized at the point at which yields were calculated. In the present work, yields were calculated for lower initial alkane mixing ratios with a larger fraction of the initial alkane reacted. Because higher initial alkane mixing ratio and lower extent of alkane reacted have opposite effects on SOA yield that are difficult to decouple, comparison of absolute measurements between Lim and Ziemann (2009b) and the present work are not instructive. Presto et al. (2010) reported SOA yields for dodecane oxidation for 19.1 and $57.8 \mathrm{ppbv}$ initial alkane, and Tkacik et al. (2012) reported SOA yields from 2-methylundecane oxidation for a low alkane mixing ratio (initial alkane mixing ratios were not specified). Both studies parameterized yields using the volatility basis set (VBS) 


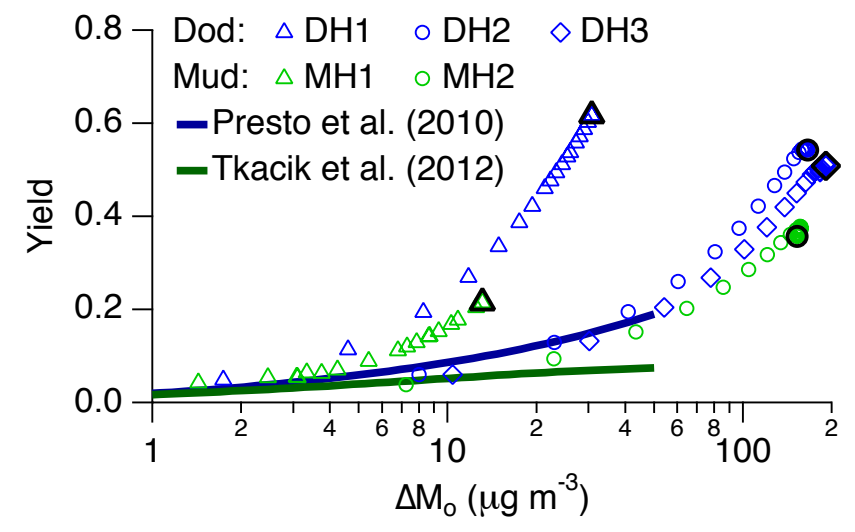

Fig. 3. Comparison of SOA yields as a function of organic aerosol mass concentration, $\Delta M_{\mathrm{O}}$, observed in the present study with those reported in previous studies. For the present study, final yields (after $95-100 \%$ alkane reacted) are denoted by the black markers.

for $\Delta M_{\mathrm{o}}<50 \mu \mathrm{g} \mathrm{m}{ }^{-3}$. A comparison of the present work to these studies is shown in Fig. 3. Both Presto et al. (2010) and Tkacik et al. (2012) report the upper limit to particle wall losses. For comparison to these previous studies, the upper limit to particle wall losses and a unit SOA density were used to calculate yields for experiments DH1, DH2, DH3, MH1, and MH2 shown in Fig. 3. The dodecane VBS parameterization presented by Presto et al. (2010) matches the higher final $\Delta M_{\mathrm{O}}$ dodecane experiments, $\mathrm{DH} 2$ and $\mathrm{DH} 3$, for $\Delta M_{\mathrm{o}}<50 \mu \mathrm{g} \mathrm{m}^{-3}$; however, it does not match the lower final $\Delta M_{\mathrm{o}}$ dodecane experiment, DH1. This discrepancy can be attributed to different $\mathrm{OH}$ exposure. Presto et al. (2010) achieved an $\mathrm{OH}$ exposure of approximately $1.2 \times$ $10^{7}$ molec $\mathrm{cm}^{-3} \mathrm{~h}$ and did not react all of the parent alkane, whereas $\mathrm{OH}$ exposure in the present experiments was approximately $7 \times 10^{7}$ molec $\mathrm{cm}^{-3} \mathrm{~h}$ and at $>95 \%$ of the parent alkane reacted. Similar results are observed when comparing 2-methylundecane yields from Tkacik et al. (2012) with those in the present study. The $\mathrm{OH}$ exposure achieved

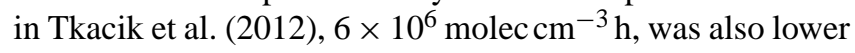
than that achieved in the present work.

\subsection{Low-NO ${ }_{\mathrm{x}}$ SOA yield measurements}

Conditions for low- $\mathrm{NO}_{\mathrm{x}}$ experiments are presented in Table 3. $\Delta M_{\mathrm{o}}$ and SOA yield measurements are reported after $30-36 \mathrm{~h}$ irradiation, corresponding to $\mathrm{OH}$ exposures of $(6-12) \times 10^{7} \mathrm{molec} \mathrm{cm}^{-3} \mathrm{~h}$, for which at least $95 \%$ of the initial alkane reacted. Figure $2 b$ shows the SOA yield after $30-36 \mathrm{~h}$ irradiation, and, as for the high- $\mathrm{NO}_{\mathrm{x}}$ data, the top and bottom of each line correspond to the upper and lower limits to the particle wall-loss correction, respectively. The highest yields are observed for cyclododecane, followed by hexylcyclohexane, with the yields for dodecane and 2methylundecane being similar. The ordering of hexylcyclohexane, dodecane, and 2-methylundecane yields is different from that observed under high- $\mathrm{NO}_{\mathrm{x}}$ conditions and will be discussed further in Sect. 3.4. As with the high- $\mathrm{NO}_{\mathrm{x}}$ yields, there are no compound-specific trends for SOA yield with initial alkane concentration.

SOA yields under low- $\mathrm{NO}_{\mathrm{x}}$ conditions have not been reported previously for the compounds studied here. SOA yields under low- $\mathrm{NO}_{\mathrm{x}}$ conditions have been reported for $n$-decane and $n$-pentadecane in a Potential Aerosol Mass flow reactor (Lambe et al., 2012). Lambe et al. (2012) reported maximum yields of 0.39 and 0.69 at $\mathrm{OH}$ exposures of $1.4 \times 10^{8}$ and $9.7 \times 10^{7}$ molec cm $^{-3} \mathrm{~h}$ and SOA concen-

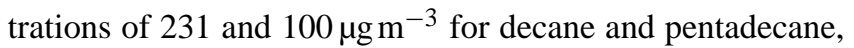
respectively. The dodecane SOA yield is expected to lie between those for longer and shorter chain alkanes; however, the dodecane SOA yields measured in the present study (Table 3) are less than that measured for $231 \mu \mathrm{g} \mathrm{m}^{-3}$ decane, a much larger initial concentration than those used in the present experiments, by Lambe et al. (2012) at similar OH exposure. Lambe et al. (2012) note that the maximum SOA yield for pentadecane at $16 \mu \mathrm{g} \mathrm{m}^{-3}$ is 0.21 , which is in much better agreement with the dodecane SOA concentrations and SOA yields in the present study.

\subsection{SOA growth parameterization}

In Fig. 3, it is interesting to note that different SOA yields are observed from the same alkane and $\Delta M_{\mathrm{o}}$ for different initial alkane mixing ratios (e.g., at $\Delta M_{\mathrm{o}}=10 \mu \mathrm{g} \mathrm{m}^{-3}$, the yield from 9 ppbv dodecane, DH1, is 0.27 , whereas the yield from 57-61 ppbv dodecane, DH2 and DH3, is 0.06). This trend is observed for all four compounds under both highand low- $\mathrm{NO}_{\mathrm{x}}$ conditions and suggests that there may be an alternative to parameterizing yields for these alkanes in terms of $\Delta M_{\mathrm{o}}$ (i.e., assuming quasi-equilibrium growth).

Shiraiwa et al. (2013) predicted that the behavior of the particle size distribution during low- $\mathrm{NO}_{\mathrm{x}}$ dodecane photooxidation is consistent with kinetically limited, rather than quasi-equilibrium, growth. Other ambient and laboratory studies also suggest that SOA growth can be kinetically limited (Riipinen et al., 2011; Perraud et al., 2012). For kinetically limited SOA growth, SOA yield should be a function of total particle surface area; however, for the same alkane and $\mathrm{NO}_{\mathrm{x}}$ conditions and a given particle surface area, different SOA yields were observed, similar to the results presented in Fig. 3. Instead, SOA yields were parameterized by number of semivolatile organic compound (SVOC)-particle collisions. Total SVOC concentration was simulated for the case of dodecane low- $\mathrm{NO}_{\mathrm{x}}$ photooxidation using a kinetic multilayer model of gas-particle interactions (KM-GAP) (Shiraiwa et al., 2012; Shiraiwa and Seinfeld, 2012; Shiraiwa et al., 2013). KM-GAP explicitly resolves mass transport and chemical reactions in the gas and particle phases. The cumulative number of SVOC-particle collisions per unit chamber volume, $C_{\text {sum }}$, was calculated from the SVOC concentration and total particle surface area. Details of these calculations 
Table 3. Low- $\mathrm{NO}_{\mathrm{x}}$ experimental details.

\begin{tabular}{|c|c|c|c|c|c|c|}
\hline Expt. $^{\mathrm{a}}$ & Alkane & $\begin{array}{r}\text { Seed vol. } \\
\left(\mu \mathrm{m}^{3} \mathrm{~cm}^{-3}\right)\end{array}$ & $\begin{array}{r}\mathrm{HC}_{\mathrm{o}} \\
(\mathrm{ppbv})\end{array}$ & $\begin{array}{r}\Delta \mathrm{HC} \\
(\mathrm{ppbv})\end{array}$ & $\begin{array}{r}\Delta M_{\mathrm{o}}^{\mathrm{b}} \\
\left(\mu \mathrm{g} \mathrm{m}^{-3}\right)\end{array}$ & $\begin{array}{l}\text { Yield }^{b} \\
\text { (frac.) }\end{array}$ \\
\hline ML1 & Mud & $21.8 \pm 6.5$ & $8.5 \pm 0.3$ & 8.4 & $7.9-15$ & $0.14-0.27$ \\
\hline $\mathrm{ML}^{\mathrm{c}}$ & Mud & $16.7 \pm 5.0$ & $28.9 \pm 0.9$ & 28.1 & $28-58$ & $0.15-0.31$ \\
\hline ML3 & Mud & $15.9 \pm 4.8$ & $40.2 \pm 1.3$ & 38.1 & $49-86$ & $0.19-0.33$ \\
\hline DL1 & Dod & $16.7 \pm 5.0$ & $8.2 \pm 0.3$ & 7.9 & $1.8-4.2$ & $0.033-0.078$ \\
\hline $\mathrm{DL} 2^{\mathrm{c}}$ & Dod & $12.1 \pm 3.6$ & $34.0 \pm 1.1$ & 33.6 & $35-65$ & $0.15-0.28$ \\
\hline $\mathrm{HL}_{1}^{\mathrm{c}}$ & Hch & $11.2 \pm 3.4$ & $15.6 \pm 0.5$ & 15.5 & $33-70$ & $0.30-0.65$ \\
\hline HL2 & Hch & $20.0 \pm 6.0$ & $41.3 \pm 1.3$ & 40.8 & 99-120 & $0.35-0.44$ \\
\hline CL1 & Cdd & $18.9 \pm 5.7$ & $3.5 \pm 0.1$ & 3.4 & $4.9-11$ & $0.22-0.46$ \\
\hline $\mathrm{CL} 2^{\mathrm{c}}$ & Cdd & $15.3 \pm 4.6$ & $10.4 \pm 0.3$ & 10.3 & $30-62$ & $0.42-0.86$ \\
\hline CL3 & Cdd & $21.5 \pm 6.5$ & $46.6 \pm 1.5$ & 45.1 & $200-230$ & $0.61-0.73$ \\
\hline
\end{tabular}

a The first letter of each experiment identifier refers to the alkane, and the second letter refers to high- $(\mathrm{H})$ or low(L) $\mathrm{NO}_{\mathrm{x}}$ conditions.

$\mathrm{b}$ The range of values listed corresponds to the two limiting assumptions for suspended vapor-deposited particle gas-particle partitioning. The smaller and larger values correspond to the upper and lower partitioning limits, respectively.

${ }^{c}$ Due to chamber volume limitations, these experiments were run in two parts. The initial conditions for the two separate experiments are listed Table S2.

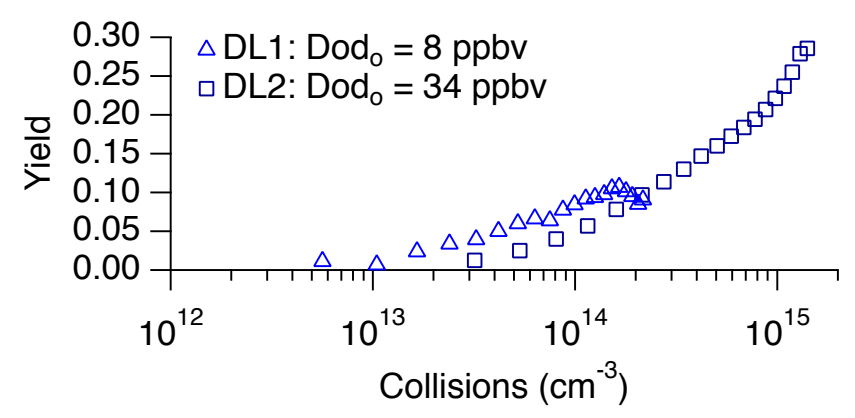

Fig. 4. SOA yield (upper limit) as a function of estimated cumulative SVOC-particle collisions per unit chamber volume for low$\mathrm{NO}_{\mathrm{X}}$ dodecane photooxidation experiments.

are given in Appendix C. Figure 4 shows yield as a function of $C_{\text {sum }}$ for the dodecane low- $\mathrm{NO}_{\mathrm{x}}$ photooxidation system. Calculations were made with a time resolution of $3 \mathrm{~min}$, but hourly averaged data are displayed. The SOA yields from both experiments trend similarly with $C_{\text {sum }}$. This result indicates that analysis of chamber experiments for any SOA system with kinetic-flux modeling is instructive and provides an alternative to parameterizing SOA yields as a function of $\Delta M_{\mathrm{o}}$.

\subsection{Aerosol chemical composition}

Organonitrates have been identified previously as products from alkane high- $\mathrm{NO}_{\mathrm{x}}$ photooxidation and are expected to be present in the particle phase (Lim and Ziemann, 2005). The AMS can detect organic nitrates as $\mathrm{NO}^{+}$and $\mathrm{NO}_{2}^{+}$, but inorganic nitrates also contribute signal to these ions (Farmer et al., 2010). During the high- $\mathrm{NO}_{\mathrm{x}}$ experiments, $\mathrm{NO}^{+}$and $\mathrm{NO}_{2}^{+}$trend with organic growth measured by the AMS. Dur- ing this time, nitric acid is also formed from reaction of $\mathrm{NO}_{2}$ with $\mathrm{OH}$ and can partition to particles and interact with the ammonium sulfate seed. The ratio of $\mathrm{NO}^{+}: \mathrm{NO}_{2}^{+}$observed during photooxidation experiments is higher than that from AMS ionization efficiency calibrations, in which ammonium nitrate is atomized into the AMS, indicating that the $\mathrm{NO}^{+}$ and $\mathrm{NO}_{2}^{+}$signals are not likely from inorganic nitrates. Because there is evidence that the signals for $\mathrm{NO}^{+}$and $\mathrm{NO}_{2}^{+}$ likely come from organonitrates in the present experiments, these ions are included when calculating the total organic mass from AMS data. According to a proposed decomposition pathway for organonitrates (Francisco and Krylowski, 2005; Farmer et al., 2010), the oxygens in $\mathrm{NO}^{+}$and $\mathrm{NO}_{2}^{+}$are not bound directly to a carbon atom. Therefore, the ion signals at $\mathrm{NO}^{+}$and $\mathrm{NO}_{2}^{+}$were not included in elemental ratios used to calculate average carbon oxidation state.

Average carbon oxidation state, $\overline{\mathrm{OS}}_{\mathrm{C}}$, (Kroll et al., 2011) was calculated from AMS measurements for comparison of the alkane systems. SOA $\overline{\mathrm{OS}}_{\mathrm{C}}$ from each parent alkane showed similar trends with respect to initial alkane mixing ratio, $\mathrm{NO}_{\mathrm{x}}$ conditions, and $\mathrm{OH}$ exposure; therefore, data only for cyclododecane are shown in Fig. 5. Under both highand low- $\mathrm{NO}_{\mathrm{x}}$ conditions, SOA formed from a lower initial cyclododecane mixing ratio was characterized by a higher $\overline{\mathrm{OS}}_{\mathrm{C}}$. This trend has been observed in other systems (Shilling et al., 2009) and is expected because a higher initial alkane mixing ratio increases the mixing ratios of semivolatile products, which have lower $\overline{\mathrm{OS}}_{\mathrm{C}}$ than low volatility products, in both the gas and particle phases. Under low- $\mathrm{NO}_{\mathrm{x}}$ conditions, SOA $\overline{\mathrm{OS}}_{\mathrm{C}}$ decreases for $\mathrm{OH}$ exposures of 0 $2 \times 10^{7}$ molec $\mathrm{cm}^{-3} \mathrm{~h}$ and then gradually increases with increasing $\mathrm{OH}$ exposure. Other studies have reported similar trends for $\mathrm{O}: \mathrm{C}$ formed under low- $\mathrm{NO}_{\mathrm{x}}$ conditions (Lambe et al., 2012; Loza et al., 2012). This trend is attributed to 


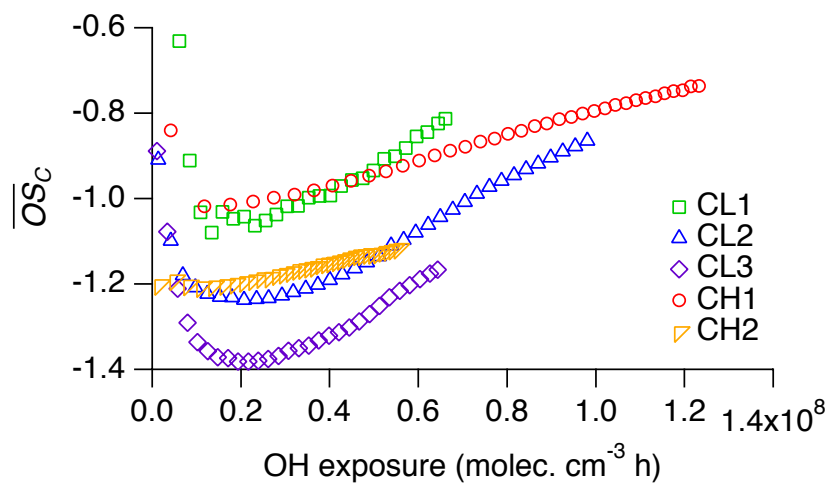

Fig. 5. SOA average carbon oxidation state as a function of $\mathrm{OH}$ exposure for high- and low- $\mathrm{NO}_{\mathrm{x}}$ cyclododecane photooxidation.

initial condensation of a small amount of low-volatility oxidation products followed by condensation of semivolatile products as the SOA mass increases, and then condensation of more low-volatility products as gas-phase oxidation progresses. Under low- $\mathrm{NO}_{\mathrm{x}}$ conditions, over $95 \%$ of the aerosol mass measured by the AMS in the present experiments comes from ions with chemical formulae of $\mathrm{C}_{\mathrm{x}} \mathrm{H}_{\mathrm{y}}^{+}$, $\mathrm{C}_{\mathrm{x}} \mathrm{H}_{\mathrm{y}} \mathrm{O}^{+}$, and $\mathrm{C}_{\mathrm{x}} \mathrm{H}_{\mathrm{y}} \mathrm{O}_{2}^{+}$. Note that for both $\mathrm{NO}_{\mathrm{x}}$ conditions, the ions $\mathrm{O}^{+}, \mathrm{HO}^{+}$and $\mathrm{H}_{2} \mathrm{O}^{+}$are included in the mass fraction of $\mathrm{C}_{\mathrm{x}} \mathrm{H}_{\mathrm{y}} \mathrm{O}_{2}^{+}$ions because these concentrations of these ions are calculated from that of $\mathrm{CO}_{2}^{+}$. Initially, the contributions of ions with formula $\mathrm{C}_{\mathrm{x}} \mathrm{H}_{\mathrm{y}}^{+}$are approximately equal to the sum of those with formulae $\mathrm{C}_{\mathrm{x}} \mathrm{H}_{\mathrm{y}} \mathrm{O}^{+}$and $\mathrm{C}_{\mathrm{x}} \mathrm{H}_{\mathrm{y}} \mathrm{O}_{2}^{+}$, but as $\mathrm{OH}$ exposure increases to $2 \times 10^{7} \mathrm{molec}^{-3} \mathrm{~h}$, the contributions from ions with formula $\mathrm{C}_{\mathrm{x}} \mathrm{H}_{\mathrm{y}}^{+}$begin to dominate, presumably as more semivolatile species condense. At $\mathrm{OH}$ exposures above $2 \times 10^{7} \mathrm{molec}^{-3} \mathrm{~h}$, contributions from ions with formulae $\mathrm{C}_{\mathrm{x}} \mathrm{H}_{\mathrm{y}} \mathrm{O}^{+}$and $\mathrm{C}_{\mathrm{x}} \mathrm{H}_{\mathrm{y}} \mathrm{O}_{2}^{+}$increase and those with formula $\mathrm{C}_{\mathrm{x}} \mathrm{H}_{\mathrm{y}}^{+}$decrease but still comprise a majority of the organic mass. For low- $\mathrm{NO}_{\mathrm{x}}$ alkane photooxidation, it has been suggested that peroxyhemiacetal formation triggers initial SOA growth (Yee et al., 2012, 2013; Shiraiwa et al., 2013). The hydroperoxides thought to contribute to initial peroxyhemiacetal formation, such as the carbonyl hydroperoxide, have multiple functional groups, which could explain the initial, higher $\overline{\mathrm{OS}}_{\mathrm{C}}$ values. As the particles grow, other, less functionalized oxidation products can also condense, decreasing $\overline{\mathrm{OS}}_{\mathrm{C}}$. As oxidation continued, multiple generations of gas-phase oxidation products, such as hydroxy carbonyl hydroperoxides and dicarbonyl hydroperoxides, were observed in dodecane photoxidation and proposed for cyclododecane photoxidation and also could partition to particles, increasing $\overline{\mathrm{OS}}_{\mathrm{C}}$. Although the proposed SOA products have multiple oxygen moities, much of the carbon chain is not functionalized, and $\mathrm{C}_{\mathrm{x}} \mathrm{H}_{\mathrm{y}}^{+}$fragments are expected to dominate the mass spectrum.

Under high- $\mathrm{NO}_{\mathrm{x}}$ conditions, an initial decrease in $\overline{\mathrm{OS}}_{\mathrm{C}}$ was not prominent, and the increase in $\overline{\mathrm{OS}}_{\mathrm{C}}$ as $\mathrm{OH}$ expo- sure increased was less when compared to that under low$\mathrm{NO}_{\mathrm{x}}$ conditions. When comparing high- and low- $\mathrm{NO}_{\mathrm{x}}$ experiments with similar initial cyclododecane mixing ratio (CL2 with $\mathrm{CH} 1$ or $\mathrm{CL} 3$ with $\mathrm{CH} 2$ ), SOA formed under high- $\mathrm{NO}_{\mathrm{x}}$ conditions has a higher $\overline{\mathrm{OS}}_{\mathrm{C}}$ during SOA growth but similar $\overline{\mathrm{OS}}_{\mathrm{C}}$ after all cyclododecane reacted. These trends indicate that less $\mathrm{OH}$ exposure is required to form low-volatility products under high- $\mathrm{NO}_{\mathrm{x}}$ conditions than under low- $\mathrm{NO}_{\mathrm{x}}$ conditions. A similar trend was observed by Presto et al. (2009), who used a thermodenuder to measure the volatility of heptadecane SOA formed under high- and low- $\mathrm{NO}_{\mathrm{x}}$ conditions. The estimated vapor pressures of many of the condensible species produced under high- and low- $\mathrm{NO}_{\mathrm{x}}$ dodecane photooxidation are similar (Jordan et al., 2008; Yee et al., 2012), but the experimental conditions control the rate at which these compounds are formed.

Alkane oxidation by $\mathrm{OH}$ generates $\mathrm{RO}_{2}$, which can react with $\mathrm{NO}, \mathrm{HO}_{2}$, or another $\mathrm{RO}_{2} \cdot \mathrm{RO}_{2}$ can also react with $\mathrm{NO}_{2}$, but the peroxynitrates formed quickly decompose back to $\mathrm{RO}_{2}$ and $\mathrm{NO}_{2}$; this pathway will not be considered here. In the present experiments, $\mathrm{RO}_{2}$ reacted primarily with $\mathrm{HO}_{2}$ under low- $\mathrm{NO}_{\mathrm{x}}$ conditions and with $\mathrm{NO}$ under high- $\mathrm{NO}_{\mathrm{x}}$ conditions. NO mixing ratio was measured directly and varied from 2-100 ppbv, and $\mathrm{HO}_{2}$ concentration was estimated from a photochemical model as approximately $1 \times 10^{10} \mathrm{~cm}^{-3}$ (Yee et al., 2012). Using $\mathrm{RO}_{2}$ reaction rate constants from the Master Chemical Mechanism 3.2 (http://mcm.leeds.ac.uk/MCM; Jenkin et al., 2003; Saunders et al., 2003), the lifetimes of $\mathrm{RO}_{2}$ reaction with $\mathrm{NO}$ and $\mathrm{HO}_{2}$ are estimated as 0.04-2 and $4 \mathrm{~s}$, respectively. Shorter $\mathrm{RO}_{2}$ lifetimes under high- $\mathrm{NO}_{\mathrm{x}}$ conditions will allow lowvolatility products to form at lower $\mathrm{OH}$ exposures.

\subsection{Effect of gas-phase fragmentation reactions on SOA yield}

For a number of SOA systems, SOA yields are higher under low-NO $\mathrm{NO}_{\mathrm{x}}$ conditions than under high-NO conditions (e.g., Song et al., 2005; $\mathrm{Ng}$ et al., 2007a; Eddingsaas et al., 2012). A likely explanation is that alkoxy radicals (RO) produced from the reaction of alkyl peroxy radicals $\left(\mathrm{RO}_{2}\right)$ and NO undergo fragmentation to form higher volatility species, whereas hydroperoxides produced from the reaction of $\mathrm{RO}_{2}$ and $\mathrm{HO}_{2}$ do not. With less fragmentation under low- $\mathrm{NO}_{\mathrm{x}}$ conditions, the carbon chain is preserved, resulting in higher yields when compared with those observed for high- $\mathrm{NO}_{\mathrm{x}}$ conditions. For linear alkanes with $>6$ carbons, isomerization of RO is favored over fragmentation reactions or reaction with $\mathrm{O}_{2}$, preserving the carbon chain and producing compounds of lower volatility than fragmentation products (Lim and Ziemann, 2009a). As a result, yields under lowand high- $\mathrm{NO}_{\mathrm{x}}$ conditions for these larger alkanes are similar, as shown in Fig. 2.

Additional trends between alkane structure, bulk SOA chemical composition, and SOA yield can be observed from 

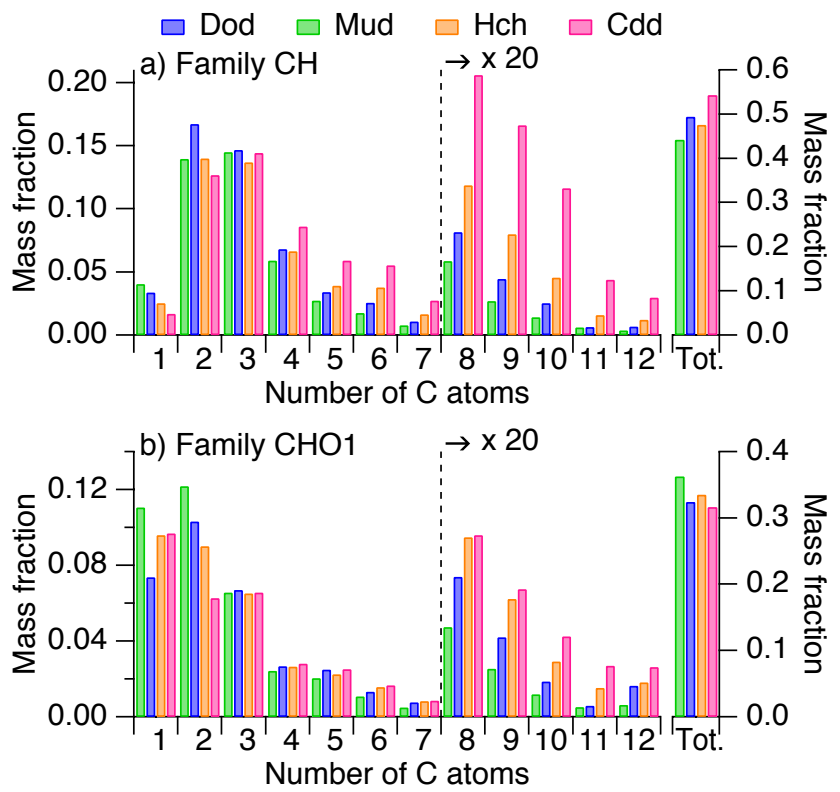

Fig. 6. Contribution of ions detected in the AMS to the bulk organic mass concentration for high- $\mathrm{NO}_{\mathrm{x}}$ alkane photooxidation. Ions are grouped into families according to the ion atomic composition and displayed as a function of carbon atoms in the ion. Tot. is the sum over all carbon atom numbers for each family. The data represent a 30 min average of the SOA formed after $95-100 \%$ of the initial alkane had reacted. The data presented are from experiments DH2, $\mathrm{MH} 2, \mathrm{HH} 2$, and $\mathrm{CH} 2$.

the AMS mass spectra. Ions can be grouped into "families" according to their elemental composition. The mass spectra are dominated by ions in family $\mathrm{CH}$, ions with formula $\mathrm{C}_{\mathrm{x}} \mathrm{H}_{\mathrm{y}}^{+}$, and family $\mathrm{CHO} 1$, ions with formula $\mathrm{C}_{\mathrm{x}} \mathrm{H}_{\mathrm{y}} \mathrm{O}^{+}$. Figures 6 and 7 show the contribution of ions in each family as a function of the number of carbon atoms in each ion and the total family contribution for a $30 \mathrm{~min}$ averaged sample obtained after $95-100 \%$ of the initial alkane mixing ratio reacted. Only data from experiments with higher alkane mixing ratio ( $>50 \mathrm{ppbv}$ and $>25 \mathrm{ppbv}$ for high- and low- $\mathrm{NO}_{\mathrm{x}}$, respectively) are shown; similar trends were observed in experiments with lower initial alkane mixing ratios. In the present study, an increase in yield is characterized by larger mass fractions of ions containing nine or more carbon atoms for both families $\mathrm{CH}$ and $\mathrm{CHO}$. Pearson's correlation coefficients for each carbon number are given in Tables S4 and S5 for family $\mathrm{CH}$ and family $\mathrm{CHO} 1$, respectively. Under high$\mathrm{NO}_{\mathrm{x}}$ conditions, the total mass fractions of family $\mathrm{CH}$ ions for cyclododecane and dodecane SOA are higher than those for 2-methylundecane and hexylcylohexane SOA (Fig. 6a), and the trend is reversed for ions in family CHO1 (Fig. 6b). The same trend is not observed under low- $\mathrm{NO}_{\mathrm{x}}$ conditions; although, compounds with a larger mass fraction of family $\mathrm{CH}$ ions have smaller mass fractions of family $\mathrm{CHO} 1$ ions. These trends provide insight into the significance of gas-
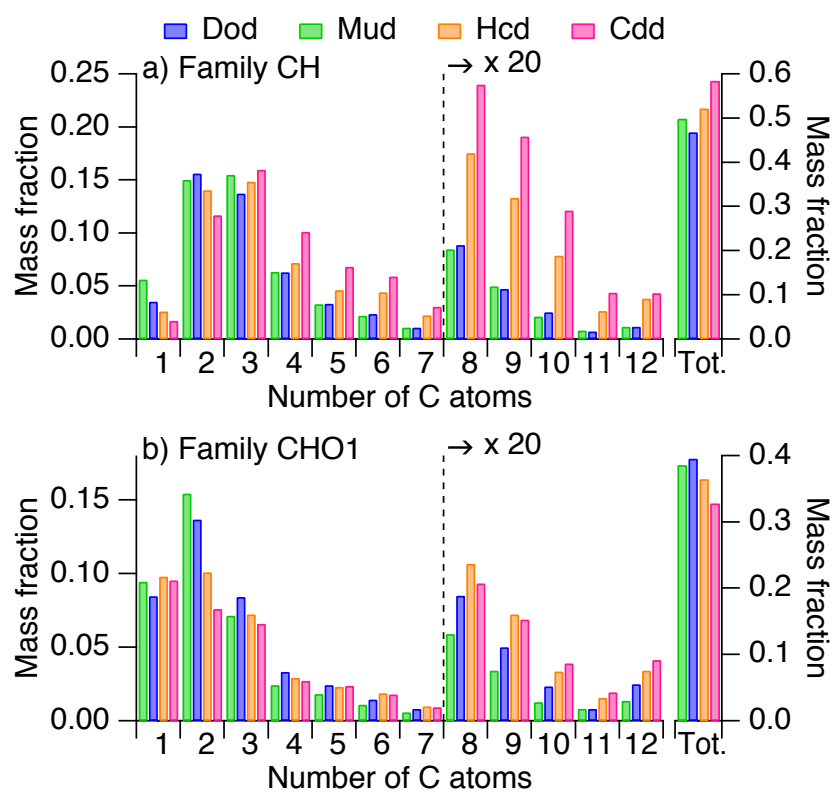

Fig. 7. Contribution of ions detected in the AMS to the bulk organic mass concentration for low- $\mathrm{NO}_{\mathrm{x}}$ alkane photooxidation. Ions are grouped into families according to the ion atomic composition and displayed as a function of carbon atoms in the ion. Tot. is the sum over all carbon atom numbers for each family. The data represent a $60 \mathrm{~min}$ average of the SOA formed after $95-100 \%$ of the initial alkane had reacted. The data presented are from experiments DL2, ML2, HL2, and CL3.

phase fragmentation reactions under high- and low- $\mathrm{NO}_{\mathrm{x}}$ conditions.

During photooxidation, the prevalence of branching in a compound is expected to lead to increased fragmentation, requiring more functionalization to produce condensible species. Greater functionalization increases the oxygen content of product molecules, thus it is reasonable that SOA from branched compounds, 2-methylundecane and hexylcyclohexane, has a higher mass fraction of family $\mathrm{CHO} 1$ ions than that from compounds with less branching, cyclododecane and dodecane. These trends are not as apparent under low- $\mathrm{NO}_{\mathrm{x}}$ conditions, suggesting that the fragmentation pathway may not be as important under low- $\mathrm{NO}_{\mathrm{x}}$ conditions as under high- $\mathrm{NO}_{\mathrm{x}}$ conditions. It should be noted that while fragmentation occurs for cyclododecane oxidation products, it results in ring-opening, which preserves the carbon backbone and does not produce a higher-volatility species. Hexylcyclohexane is also a cyclic compound, and an alkoxy radical on the ring $\alpha$ to the branch point may result in ring-opening, which preserves the carbon backbone; thus, fragmentation of hexylcyclohexane will not always result in generation of species with fewer carbon atoms than the parent molecule.

Gas-phase fragmentation products from high- $\mathrm{NO}_{\mathrm{x}}$ alkane photooxidation were detected using the CIMS (Table S3). The proposed products have been grouped into "families" 
by functionality: carboxylic acid $\left(\mathrm{C}_{\mathrm{n}} \mathrm{H}_{2 \mathrm{n}} \mathrm{O}_{2}\right)$, hydroxy carboxylic acid $\left(\mathrm{C}_{\mathrm{n}} \mathrm{H}_{2 \mathrm{n}} \mathrm{O}_{3}\right)$, carbonyl nitrate $\left(\mathrm{C}_{\mathrm{n}} \mathrm{H}_{(2 \mathrm{n}-1)} \mathrm{NO}_{4}\right)$, or hydroxynitrate $\left(\mathrm{C}_{\mathrm{n}} \mathrm{H}_{(2 \mathrm{n}+1)} \mathrm{NO}_{4}\right)$, where $n$ is the number of carbon atoms in the proposed molecule. For the CIMS ions presented here, the carbon chain is preserved as ionization occurs, whereas heating and ionization in the AMS tends to break the carbon chain, and the ions presented in Figs. 6 and 7 could come from longer chain parent molecules. Figure 8 shows the signal for each product, normalized by $\triangle H C$ for a $30 \mathrm{~min}$ averaged sample obtained after $95-100 \%$ of the initial alkane mixing ratio reacted. The data are presented assuming that CIMS sensitivity is independent of $n$ for a given family and that sensitivity is the same for all isomers (including cyclic and branched structures) for a given $n$ and family. Mixing ratio calibrations were not performed for all species presented, and trends of ion signal with carbon number are not evaluated. Because the CIMS has unit mass resolution and can detect ions produced as transfer $\left(m / z=[\mathbf{M}+19]^{-}\right)$and cluster $\left(m / z=[\mathbf{M}+85]^{-}\right)$products, the signals in Fig. $8 \mathrm{~b}$ could come from an acid or a hydroperoxide. Under high- $\mathrm{NO}_{\mathrm{x}}$ conditions, hydroperoxide production is not expected. For almost all products shown in Fig. 8, signals in the cyclododecane experiment are lower than those for the other three alkanes, suggesting that cyclododecane oxidation products undergo little fragmentation, consistent with trends obtained from AMS data. More fragmentation of 2-methylundecane and hexylcyclohexane oxidation products is expected than for those of dodecane; however, the signal from fragmentation products for most families are similar for dodecane, 2-methylundecane, and hexylcyclohexane, suggesting that some fragmentation also occurs during dodecane high- $\mathrm{NO}_{\mathrm{x}}$ photooxidation.

Gas-phase fragmentation reactions can also occur under low- $\mathrm{NO}_{\mathrm{x}}$ conditions from hydroperoxide photolysis (Yee et al., 2012, 2013). Photolysis of a hydroperoxide forms an alkoxy radical, which can isomerize or decompose depending on the carbon backbone structure. For dodecane, hydroperoxide photolysis is expected to be a minor reaction pathway compared with $\mathrm{OH}$ oxidation. The specific case of photolysis of a hydroperoxy group adjacent to a carbonyl produces an aldehyde, which has been shown to react with hydroperoxides to form peroxyhemiacetals. Peroxyhemiacetal formation is proposed to initiate SOA growth in the alkane low- $\mathrm{NO}_{\mathrm{x}}$ photooxidation system (Yee et al., 2012, 2013; Shiraiwa et al., 2013). In this case, fragmentation reactions depend more on the relative position of hydroperoxy and carbonyl groups than the structure of the carbon backbone.

When comparing SOA yields between low- and high- $\mathrm{NO}_{\mathrm{x}}$ conditions for each compound (Fig. 2), three dominant trends are observed. (1) Under high- $\mathrm{NO}_{\mathrm{x}}$ conditions, SOA yields at 95-100\% of the initial hydrocarbon reacted (i.e., the yield at the largest $\mathrm{OH}$ exposure for each experiment), for dodecane and cyclododecane are larger for lower initial alkane mixing ratio. (2) For hexylcyclohexane and, more notice- ably, 2-methylundecane, SOA yields under high- $\mathrm{NO}_{\mathrm{x}}$ conditions are higher when the initial alkane mixing ratio is higher. (3) SOA yields for dodecane and cyclododecane are higher under high- $\mathrm{NO}_{\mathrm{x}}$ conditions than under low- $\mathrm{NO}_{\mathrm{x}}$ conditions. Trends (1) and (2) arise from the role of fragmentation under high- $\mathrm{NO}_{\mathrm{x}}$ conditions. At higher initial alkane mixing ratios, semivolatile species can condense preferentially to particles, whereas, for lower initial alkane mixing ratios, semivolatile species remain in the gas phase for further oxidation. For linear or cyclic compounds, further oxidation decreases compound volatility, resulting in additional SOA formation and higher SOA yields. However, for branched compounds, further oxidation results in fragmentation, leading to higher volatility species that do not condense to form additional SOA. At sufficiently high $\mathrm{OH}$ exposures, fragmentation will become important for all systems that form SOA (Lambe et al., 2012), but those conditions were not reached in the present experiments. Trend (3) results from differences in the extent of fragmentation under both $\mathrm{NO}_{\mathrm{x}}$ conditions. Dodecane and 2-methylundecane have almost identical chemical structures, and one may expect these two compounds to have similar SOA yields. Under low- $\mathrm{NO}_{\mathrm{x}}$ conditions, the SOA yields for experiments ML2 and DL2 are 15$31 \%$ (however, the SOA yield observed in ML1 is higher than that observed in DL1), whereas under high- $\mathrm{NO}_{\mathrm{x}}$ conditions, higher SOA yields are observed for dodecane than for 2-methylundecane (see Tables 2 and 3). High- $\mathrm{NO}_{\mathrm{x}} \mathrm{SOA}$ yields are greater than low- $\mathrm{NO}_{\mathrm{x}}$ yields for unbranched compounds, but high- and low- $\mathrm{NO}_{\mathrm{x}} \mathrm{SOA}$ yields are similar for branched compounds as a result of enhanced fragmentation under high- $\mathrm{NO}_{\mathrm{x}}$ conditions.

\section{Conclusions}

In the present study SOA yields have been measured for linear, cyclic, and branched 12-carbon alkanes under high- and low- $\mathrm{NO}_{\mathrm{x}}$ conditions in which $95-100 \%$ of the alkane reacted. The highest SOA yields were observed from cyclic alkanes, and the presence of branch points decreased SOA yield, primarily under high- $\mathrm{NO}_{\mathrm{x}}$ conditions where vaporphase fragmentation reactions were more likely to occur. Uncertanties arise in the SOA yield measurements due to particle and vapor wall losses and result in a factor of 2-3 difference between upper and lower limits to SOA yield. Recently, Gentner et al. (2012) assessed SOA formation from diesel and gasoline vehicles and noted that SOA yields for cyclic alkanes with five- and six-membered rings, which comprise $37 \%$ of diesel and $11 \%$ of gasoline, were not well-characterized. This study presents data for one such compound, hexylcyclohexane. Hexylcyclohexane SOA yield was similar to that of dodecane under high- $\mathrm{NO}_{\mathrm{x}}$ conditions and greater than dodecane under low- $\mathrm{NO}_{\mathrm{x}}$ conditions. Lim and Ziemann (2009b) measured SOA yields for two other branched-cyclic compounds, $n$-butylcyclohexane and 

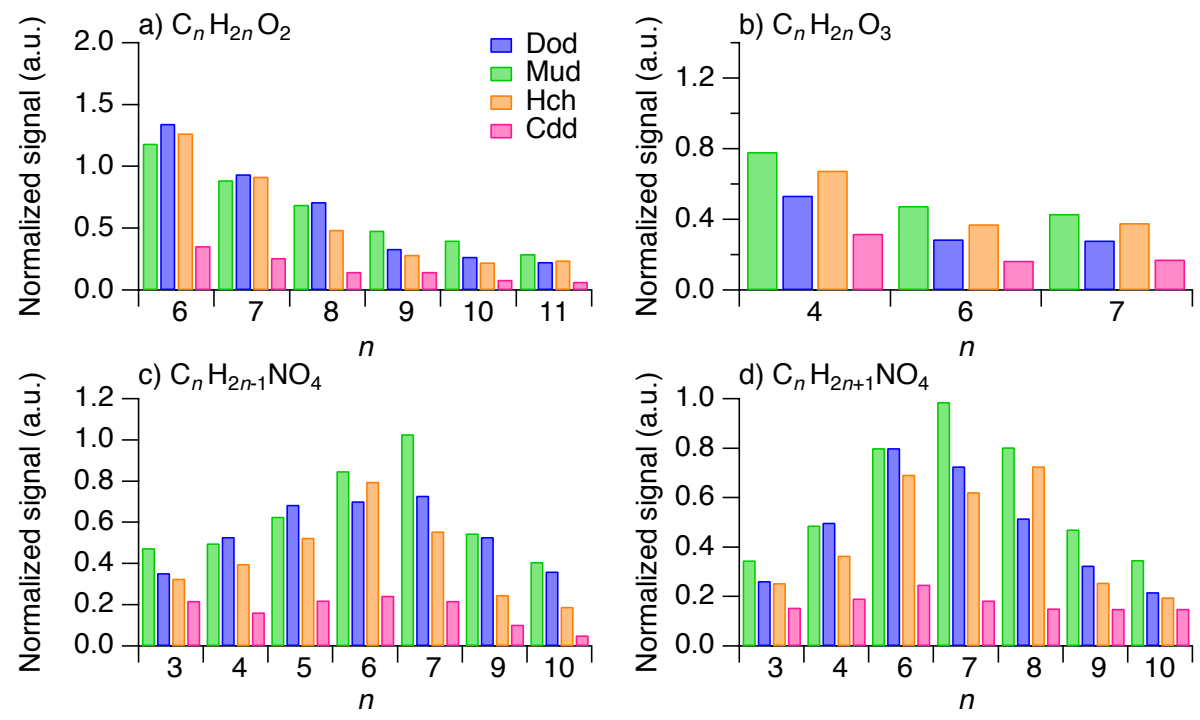

Fig. 8. Comparison of gas-phase fragmentation reaction products from high- $\mathrm{NO}_{\mathrm{x}}$ alkane photooxidation measured by the CIMS. The signal is normalized by the mixing ratio of alkane reacted. All molecular formulae are proposed assignments. The data represent a 30 min average of gas-phase species after $95-100 \%$ of the initial alkane had reacted. The ions monitored and their proposed chemical assignments are given in Table S3. The data presented are from experiments $\mathrm{DH} 3, \mathrm{MH} 2, \mathrm{HH} 2$, and $\mathrm{CH} 2$.

$n$-decylcyclohexane, under high- $\mathrm{NO}_{\mathrm{x}}$ conditions but with initial alkane mixing ratios much higher than ambient mixing ratios, approximately $1 \mathrm{ppmv}$. The authors found that the SOA yield for butylcyclohexane was higher than that for decane, but the yield for decylcyclohexane was less than that for hexadecane. Further characterization of yields from branched-cyclic compounds is necessary to better identify trends and provide more data for models.

Although alkanes are emitted primarily in urban areas under high- $\mathrm{NO}_{\mathrm{x}}$ oxidizing conditions, their relatively slow $\mathrm{OH}$ reaction rates allow for transport to rural areas with lower $\mathrm{NO}_{\mathrm{x}}$ conditions. SOA yields measured in the present study are higher or the same under high- $\mathrm{NO}_{\mathrm{x}}$ conditions in comparison to those measured for low- $\mathrm{NO}_{\mathrm{x}}$ conditions. Therefore, alkanes exhibit the largest SOA formation potential in urban areas close to their sources.

\section{Appendix A}

\section{Particle wall-loss calculations}

Pierce et al. (2008) developed the Aerosol Parameter Estimation model to determine the time variance of particle wallloss rates during an environmental chamber experiment. We have adapted this model to calculate the mass growth rate of suspended particles throughout an experiment. These mass growth rates are then applied to deposited particles to calculate lower and upper limit wall-loss corrections.

The model utilized in the current work is based on the aerosol General Dynamic Equation (Seinfeld and Pandis,
2006):

$$
\begin{aligned}
\frac{\partial n_{\mathrm{S}}\left(D_{\mathrm{p}}, t\right)}{\partial t} & =\left(\frac{\partial n_{\mathrm{s}}\left(D_{\mathrm{p}}, t\right)}{\partial t}\right)_{\mathrm{coag}}+\left(\frac{\partial n_{\mathrm{S}}\left(D_{\mathrm{p}}, t\right)}{\partial t}\right)_{\text {cond }} \\
& +\left(\frac{\partial n_{\mathrm{S}}\left(D_{\mathrm{p}}, t\right)}{\partial t}\right)_{\mathrm{wl}},
\end{aligned}
$$

where $n_{\mathrm{S}}\left(D_{\mathrm{p}}, t\right)\left(\mathrm{cm}^{-3} \mathrm{~cm}^{-1}\right)$ is the suspended particle number-size distribution, $D_{\mathrm{p}}(\mathrm{cm})$ is particle diameter, $t(\mathrm{~s})$ is time, and coag, cond, and wl represent the change in suspended particle size-number distribution due to coagulation, condensation, and particle-phase wall loss, respectively.

The change in the suspended particle number-size distribution due to coagulation is described by

$$
\begin{aligned}
& \left(\frac{\partial n_{\mathrm{s}}\left(D_{\mathrm{p}}, t\right)}{\partial t}\right)_{\text {coag }}=\frac{1}{2} \int_{0}^{D_{\mathrm{p}}} K\left(\left(D_{\mathrm{p}}^{3}-q^{3}\right)^{\frac{1}{3}}, q\right) n_{\mathrm{s}} \\
& \left(\left(D_{\mathrm{p}}^{3}-q^{3}\right)^{\frac{1}{3}}, t\right) n_{\mathrm{s}}(q, t) \mathrm{d} q-n_{\mathrm{s}}\left(D_{\mathrm{p}}, t\right) \int_{0}^{\infty} K\left(q, D_{\mathrm{p}}\right) \\
& n_{\mathrm{S}}(q, t) \mathrm{d} q,
\end{aligned}
$$

where $K\left(D_{\mathrm{p} 1}, D_{\mathrm{p} 2}\right)\left(\mathrm{cm}^{3} \mathrm{~s}^{-1}\right)$ is the coagulation coefficient for collisions of particles with diameters $D_{\mathrm{p} 1}$ and $D_{\mathrm{p} 2}$ (Seinfeld and Pandis, 2006). The DMA measures particle numbersize distributions using discrete size bins, and the coagulation coefficient must also be discretized to be applied to these data. The change in suspended particle number-size 
distribution due to coagulation becomes

$$
\begin{gathered}
\left(\frac{\partial n_{\mathrm{s}}\left(D_{\mathrm{p}}, t\right)}{\partial t}\right)_{\mathrm{coag}}=\frac{1}{2} \sum_{i} \sum_{j} f_{\mathrm{c}}\left(D_{\mathrm{p} i}, D_{\mathrm{p} j}\right) \\
K\left(D_{\mathrm{p} i}, D_{\mathrm{p} j}\right) N\left(D_{\mathrm{p} i}, t\right) N\left(D_{\mathrm{p} j}, t\right) \\
-\sum_{i} K\left(D_{\mathrm{p} i}, D_{\mathrm{p} k}\right) N\left(D_{\mathrm{p} i}, t\right) N\left(D_{\mathrm{p} k}, t\right),
\end{gathered}
$$

where $f_{\mathrm{c}}\left(D_{\mathrm{p} i}, D_{\mathrm{p} j}\right)$ expresses whether the collision of a particle in size bin $i$ with a particle in size bin $j$ produces a particle in size bin $k$, bounded by diameters $D_{\mathrm{p} k-}$ and $D_{\mathrm{p} k+}$ :

$$
\begin{aligned}
& f_{\mathrm{c}}\left(D_{\mathrm{p} i}, D_{\mathrm{p} j}\right)=1 \text { if } D_{\mathrm{p} k-} \leq 2\left(\left(\frac{D_{\mathrm{p} i}}{2}\right)^{3}\right. \\
&\left.+\left(\frac{D_{\mathrm{p} j}}{2}\right)^{3}\right)^{\frac{1}{3}}<D_{\mathrm{p} k+}
\end{aligned}
$$

$f_{\mathrm{c}}\left(D_{\mathrm{p} i}, D_{\mathrm{p} j}\right)=0$ otherwise.

Particles are not allowed to form outside of the measured size range (Verheggen and Mozurkewich, 2006).

The change in suspended particle number-size distribution due to condensation is described by

$$
\left(\frac{\partial n_{\mathrm{s}}\left(D_{\mathrm{p}}, t\right)}{\partial t}\right)_{\text {cond }}=-\frac{\partial}{\partial D_{\mathrm{p}}}\left[I\left(D_{\mathrm{p}}, t\right) n\left(D_{\mathrm{p}}, t\right)\right],
$$

where $I\left(D_{\mathrm{p}}, t\right)\left(\mathrm{cms}^{-1}\right)$ is the rate of change of particle diameter as a result of condensation. Assuming spherical particles with a density $\rho_{\mathrm{p}}\left(\mathrm{g} \mathrm{cm}^{-3}\right)$ that is not a strong function of time,

$I\left(D_{\mathrm{p}}, t\right)=\frac{\mathrm{d} D_{\mathrm{p}}}{\mathrm{d} t}=\frac{2 \sum J_{i}}{\pi D_{\mathrm{p}}^{2} \rho_{\mathrm{p}}}$,

where $J_{i}\left(\mathrm{~g} \mathrm{~s}^{-1}\right)$ is the mass flux of species $i$ to the particle. $J_{i}$ is defined as

$$
J_{i}=\frac{2 \pi D_{\mathrm{p}} D_{i} M_{i}}{R T} f\left(K n, \alpha_{i}\right)\left(p_{\infty, i}-p_{\mathrm{s}, i}\right),
$$

where $D_{i}\left(\mathrm{~cm}^{2} \mathrm{~s}^{-1}\right)$ is the diffusion coefficient for species $i$ in air, $M_{i}\left(\mathrm{~g} \mathrm{~mol}^{-1}\right)$ is the molecular weight of species $i, R$ $\left(\mathrm{g} \mathrm{cm}^{2} \mathrm{~s}^{-2} \mathrm{~mol}^{-1} \mathrm{~K}^{-1}\right)$ is the gas constant, $T(\mathrm{~K})$ is temperature, $f\left(K n, \alpha_{i}\right)$ is a correction factor for non-continuum effects and surface accommodation effects, $p_{\infty, i}\left(\mathrm{~g} \mathrm{~cm}^{-1} \mathrm{~s}^{-2}\right)$ is the vapor pressure of species $i$ in far from the particle, and $p_{s, i}\left(\mathrm{gcm}^{-1} \mathrm{~s}^{-2}\right)$ is the partial pressure of species $i$ at the surface of the particle. Substituting Eqs. (A7) and (A8) into Eq. (A6) yields

$$
\begin{aligned}
\left(\frac{\partial n_{\mathrm{s}}\left(D_{\mathrm{p}}, t\right)}{\partial t}\right)_{\text {cond }}= & \frac{-4}{R T \rho_{\mathrm{p}}}\left[\sum_{i} D_{i} M_{i} f\left(K n, \alpha_{i}\right)\left(p_{\infty, i}-p_{\mathrm{s}, i}\right)\right] \\
& \frac{\partial}{\partial D_{\mathrm{p}}}\left[\frac{1}{D_{\mathrm{p}}} n_{\mathrm{s}}\left(D_{\mathrm{p}}, t\right)\right]
\end{aligned}
$$

Here we are assuming that $\rho_{\mathrm{p}}$ is constant with respect to $D_{\mathrm{p}}$ at a given time $t$. If many size bins are used to describe the particle number-size distribution, then $\rho_{\mathrm{p}}$ is likely constant over a small range of $D_{\mathrm{p}}$, and the magnitude of the error that this assumption produces is reduced. Following Pierce et al. (2008), the unknown parameters in Eq. (A9) can be combined into a single factor, $F_{\mathrm{c}}\left(\mathrm{cm}^{2} \mathrm{~s}^{-1}\right)$, defined as

$$
F_{\mathrm{c}}=\frac{4}{R T \rho_{\mathrm{p}}} \sum_{i} D_{i} M_{i} f\left(K n, \alpha_{i}\right)\left(p_{\infty, i}-p_{\mathrm{s}, i}\right) .
$$

Substituting $F_{\mathrm{c}}$ into Eq. (A9) and differentiating gives the final form for the change in suspended number-size distribution due to condensation:

$$
\left(\frac{\partial n_{\mathrm{s}}\left(D_{\mathrm{p}}, t\right)}{\partial t}\right)_{\text {cond }}=-F_{\mathrm{c}}\left[-\frac{1}{D_{\mathrm{p}}^{2}} n_{\mathrm{s}}\left(D_{\mathrm{p}}, t\right)+\frac{1}{D_{\mathrm{p}}} \frac{\partial n_{\mathrm{s}}\left(D_{\mathrm{p}}, t\right)}{\partial D_{\mathrm{p}}}\right]
$$

The model varies $F_{\mathrm{c}}$ to produce a number-size distribution that best fits the observed number distribution.

The change in suspend particle number-size distribution due to particle wall deposition is assumed to follow firstorder kinetics with particle size-dependent rate constants, $\beta\left(D_{\mathrm{p}}\right)\left(\mathrm{s}^{-1}\right)$ :

$$
\left(\frac{\partial n_{\mathrm{s}}\left(D_{\mathrm{p}}, t\right)}{\partial t}\right)_{w l}=-\beta\left(D_{\mathrm{p}}\right) n_{\mathrm{s}}\left(D_{\mathrm{p}}, t\right) .
$$

A theoretical determination of $\beta$ is described in Crump and Seinfeld (1981) and McMurry and Rader (1985); however, parameters needed to calculate $\beta$ values are difficult to quantify from theory alone for environmental chambers. Instead, $\beta$ values can be determined from calibration experiments (Keywood et al., 2004; Ng et al., 2007b; Loza et al., 2012) or can be specified as unknowns in an aerosol general dynamic model (Pierce et al., 2008). The present model employs the former parameterization of $\beta$ values. $\beta$ values for AS particles are measured during calibration experiments in which wall deposition is the dominant process affecting the number distribution. Particles containing organics are assumed to behave the same as pure AS particles.

To implement the model, the General Dynamic Equation is solved numerically between each time step for a given experimental data set. First the General Dynamic Equation is discretized into diameter size bins corresponding to those of the measured number-size distribution. Then the model is initialized with a measured number-size distribution at time step $t$ and a guess for the parameter $F_{\mathrm{c}}$. The model is solved using a Dormand Price pair 4th and 5th order Runge-Kutta method to produce a number-size distribution at time step $t+1$. The fit of the predicted to the observed number-size distributions at time step $t+1$ is quantified using various diameter moments. The $i$ th diameter moment is calculated as follows

$M_{i}=\int_{0}^{\infty} D_{\mathrm{p}}^{i} n_{\mathrm{s}}\left(D_{\mathrm{p}}\right) \mathrm{d} D_{\mathrm{p}}=\sum_{k} D_{p, k}^{i} N_{\mathrm{s}}\left(D_{p, k}\right)$, 
where $k$ is the size bin and $N_{\mathrm{s}}\left(\mathrm{cm}^{-3}\right)$ is the suspended particle number concentration. The best fit of the predicted to the observed number distribution is that which minimizes $\chi^{2}$ :

$\chi^{2}=\sum_{a=1}^{9}\left(\frac{M_{i(a), \mathrm{p}}-M_{i(a), \mathrm{o}}}{M_{i(a), \mathrm{o}}}\right)^{2}$,

where $i(a)$ is the set of diameter moments $[-1,-0.5,0,0.5,1,1.5,2,2.5,3]$ and moment subscripts $p$ and $\mathrm{o}$ are predicted and observed, respectively.

Once values for $F_{\mathrm{c}}$ have been estimated, they can be used in wall-loss corrections to parametrize the growth of particles lost to the chamber walls. The change in the deposited particle number-size distribution also is governed by the the aerosol General Dynamic Equation, but only wall loss and condensation process affect the number-size distribution:

$$
\begin{gathered}
\frac{\partial n_{\mathrm{w}}\left(D_{\mathrm{p}}, t\right)}{\partial t}=\beta\left(D_{\mathrm{p}}\right) n_{\mathrm{s}}\left(D_{\mathrm{p}}, t\right)-F_{\mathrm{c}} \omega \\
{\left[-\frac{1}{D_{\mathrm{p}}^{2}} n_{\mathrm{w}}\left(D_{\mathrm{p}}, t\right)+\frac{1}{D_{\mathrm{p}}} \frac{\partial n_{\mathrm{w}}\left(D_{\mathrm{p}}, t\right)}{\partial D_{\mathrm{p}}}\right],}
\end{gathered}
$$

where $n_{\mathrm{w}}\left(D_{\mathrm{p}}, t\right)\left(\mathrm{cm}^{-3}\right)$ is the deposited particle numbersize distribution, and $\omega$ is a factor that describes the extent of condensation to deposited particles. $\omega$ has a value between 0 (no condensation to deposited particles) and 1 (condensation to deposited particles is the same as that to suspended particles). $\omega$ values of 0 and 1 correspond to the lower and upper limits of particle wall-loss corrections, respectively. The aerosol General Dynamic Equations for suspended and deposited particles are solved simultaneously between each time step using the previously determined value for $F_{\mathrm{c}}$ at that time step and a constant value for $\omega$. In the current work, wall-loss corrections were calculated with $\omega=0$ and $\omega=1$ to evaluate the limits of condensation behavior to deposited particles.

\section{Appendix B}

\section{Effect of vapor wall losses on SOA yields}

Condensible species can partition to suspended particles, deposited particles, and the chamber walls. The SOA yields reported here account for the first two processes, but vapor wall losses are not considered. If vapors are lost to the wall instead of forming SOA, then SOA yield will be underestimated. Matsunaga and Ziemann (2010) observed vapor wall losses for alkanes, ketones, and alcohols that are relevant to compounds formed in the present systems. The extent of vapor phase wall losses in both of the Caltech chamber facilities was investigated using experiments in which a known volume of dodecanone, dodecanol, or dodecane was injected into a chamber filled with purified air. The signal for each species was monitored over a period of several hours. Dodecane wall losses were not significant in either chamber. In the $28 \mathrm{~m}^{3}$ chamber used for low- $\mathrm{NO}_{\mathrm{x}}$ experiments, 2-dodecanone wall losses followed first-order kinetics with a rate constant of $k_{\mathrm{w}}=2.2 \times 10^{-6} \mathrm{~s}^{-1}(\tau=5.3$ days $)$. In the $24 \mathrm{~m}^{3}$ chamber used for high- $\mathrm{NO}_{\mathrm{x}}$ experiments, 2dodecanol wall losses followed first-order kinetics with a rate constant of $k_{\mathrm{W}}=1.5 \times 10^{-6} \mathrm{~s}^{-1}$ ( $\tau=7.7$ days). Matsunaga and Ziemann (2010) observed $20 \%$ wall loss of 2-dodecanol in $80 \mathrm{~min}$ and $25 \%$ wall loss of 2-dodecanone in $25 \mathrm{~min}$, which equate to first order wall-loss rate constants of $k_{\mathrm{w}}=$ $3.4 \times 10^{-4} \mathrm{~s}^{-1}(\tau=49 \mathrm{~min})$ and $k_{\mathrm{w}}=9.2 \times 10^{-4} \mathrm{~s}^{-1}(\tau=$ $18 \mathrm{~min}$ ) for 2-dodecanol and 2-dodecanone, respectively; after the initial decrease, the 2-dodecanone mixing ratio remained constant for $400 \mathrm{~min}$, presumably after equilibrium was achieved between the suspended vapors and those sorbed to the walls. Equilibrium was not observed for either compound in the Caltech chambers over a $22 \mathrm{~h}$ period, and it was not possible to detect rapid initial losses in the Caltech chambers as a result of the chamber setup and injection procedures. The time required to inject measurable mixing ratios of each compound into the chamber was at least $25 \mathrm{~min}$, and because there is no active mixing in the Caltech chambers, it was necessary to wait an additional $20 \mathrm{~min}$ after the end of the injection for the chamber contents to mix. Rapid vapor wall losses occurring during this time period are difficult to distinguish from changes in compound mixing ratio due to injection and mixing. Finally, alkane photooxidation generates a variety of products with multiple functionalization; however, only singly-functionalized compounds were tested for wall loss. Matsunaga and Ziemann (2010) showed that vapor wall loss is a function of compound vapor pressure and structure; therefore, it is difficult to extrapolate wall-loss rates of 2-dodecanol and 2-dodecanone to all compounds formed from alkane photooxidation. In an attempt to quantify vapor wall losses, Shiraiwa et al. (2013) assumed vapor wall losses follow pseudo-first order kinetics and varied vapor wall-loss rate constants of SVOCs generated in KMGAP simulations of dodecane low- $\mathrm{NO}_{\mathrm{x}}$ photooxidation. Using $k_{\mathrm{w}}=9.6 \times 10^{-6} \mathrm{~s}^{-1}$, the highest value considered, led to a decrease of the SOA mass concentration by approximately $30 \%$. As a result, SOA yield would increase by $30 \%$. The combined uncertainties of vapor and particle phase wall-loss result in a factor of 2-3 difference between the upper and lower limits to SOA yields in each system.

\section{Appendix C}

\section{SVOC-particle collision calculations}

In KM-GAP, the collision flux of SVOC at the particle surface, $J_{\mathrm{A}}\left(\right.$ molec $\left.\mathrm{cm}^{-3} \mathrm{~s}^{-1}\right)$, is

$J_{\mathrm{A}}=\frac{1}{4} c_{\mathrm{A}} \bar{c}_{\mathrm{A}}$, 
where $c_{\mathrm{A}}$ is the SVOC concentration $\left(\right.$ molec $\left.\mathrm{cm}^{-3}\right)$ and $\bar{c}_{\mathrm{A}}$ is the mean molecular speed of SVOC $\left(\mathrm{cm} \mathrm{s}^{-1}\right) . J_{\mathrm{A}}$ can be calculated for discrete time points, $i$, in an experiment corresponding to particle surface area measurements. The following summation is used to calculate cumulative number of SVOC-particle collisions per unit chamber volume, $C_{\text {sum }}$ $\left(\mathrm{cm}^{-3}\right)$,

$C_{\mathrm{sum}}=\sum_{i=1}^{n} J_{\mathrm{A}, i} S_{i} \Delta t_{i}$

where $n$ is the total number of data points, $S_{i}$ is the particle surface area $\left(\mathrm{cm}^{2} \mathrm{~cm}^{-3}\right)$, and $\Delta t_{i}$ is the time between data points $i$ and $i+1$ (s). Here the upper limit wall-loss corrected surface area concentration is used to correspond to the model, which does not simulate particle wall losses.

\section{Supplementary material related to this article is available online at http://www.atmos-chem-phys.net/14/ 1423/2014/acp-14-1423-2014-supplement.pdf.}

Acknowledgements. This work was supported by the Office of Science (Biological and Environmental Research), US Department of Energy grant DE-SC 0006626 and National Science Foundation grants AGS-1057183 and ATM-0650061. We thank M. Chan for experimental assistance and A. Matsunaga for information regarding Tenax tube preparation and sampling procedures. C. Loza, L. Yee, and J. Craven were supported by National Science Foundation Graduate Research Fellowships. Manabu Shiraiwa was supported by the Japan Society for the Promotion of Science (JSPS) Postdoctoral Fellowship for Research Abroad.

Edited by: J. B. Burkholder

\section{References}

Aiken, A. C., DeCarlo, P. F., Kroll, J. H., Worsnop, D. R., Huffman, J. A., Docherty, K. S., Ulbrich, I. M., Mohr, C., Kimmel, J. R., Sueper, D., Sun, Y., Zhang, Q., Trimborn, A., Northway, M., Ziemann, P. J., Canagaratna, M. R., Onasch, T. B., Alfarra, M. R., Prévôt, A. S. H., Dommen, J., Duplissy, J., Metzger, A., Baltensperger, U., and Jimenez, J. L.: O/C and OM/OC ratios of primary, secondary, and ambient organic aerosols with highresolution time-of-flight aerosol mass spectrometry, Environ. Sci. Technol., 42, 4478-4485, doi:10.1021/es703009q, 2008.

Allan, J. D., Delia, A. E., Coe, H., Bower, K. N., Alfarra, M. R., Jimenez, J. L., Middlebrook, A. M., Drewnick, F., Onasch, T. B., Canagaratna, M. R., Jayne, J. T., and Worsnop, D. R.: A generalised method for the extraction of chemically resolved mass spectra from Aerodyne aerosol mass spectrometer data, J. Aerosol Sci., 35, 909-922, doi:10.1016/j.jaerosci.2004.02.007, 2004.

Atkinson, R. and Arey, J.: Atmospheric degradation of volatile organic compounds, Chem. Rev., 103, 4605-4638, doi:10.1021/cr0206420, 2003.
Canagaratna, M., Jayne, J., Jimenez, J., Allan, J., Alfarra, M., Zhang, Q., Onasch, T., Drewnick, F., Coe, H., Middlebrook, A., Delia, A., Williams, L., Trimborn, A., Northway, M., DeCarlo, P., Kolb, C., Davidovits, P., and Worsnop, D.: Chemical and microphysical characterization of ambient aerosols with the Aerodyne aerosol mass spectrometer, Mass Spectrom. Rev., 26, 185-222, doi:10.1002/mas.20115, 2007.

Cocker, D. R., Flagan, R. C., and Seinfeld, J. H.: State-of-theart chamber facility for studying atmospheric aerosol chemistry, Environ. Sci. Technol., 35, 2594-2601, doi:10.1021/es0019169, 2001.

Craven, J. S., Yee, L. D., Ng, N. L., Canagaratna, M. R., Loza, C. L., Schilling, K. A., Yatavelli, R. L. N., Thornton, J. A., Ziemann, P. J., Flagan, R. C., and Seinfeld, J. H.: Analysis of secondary organic aerosol formation and aging using positive matrix factorization of high-resolution aerosol mass spectra: Application to the dodecane low- $\mathrm{NO}_{\mathrm{x}}$ system, Atmos. Chem. Phys., 12, 1179511817, doi:10.5194/acp-12-11795-2012, 2012.

Crump, J. G. and Seinfeld, J. H.: Turbulent deposition and gravitational sedimentation of an aerosol in a vessel of arbitrary shape, J. Aerosol Sci., 12, 405-415, doi:10.1016/0021-8502(81)900367, 1981.

DeCarlo, P. F., Kimmel, J. R., Trimborn, A., Northway, M. J., Jayne, J. T., Aiken, A. C., Gonin, M., Fuhrer, K., Horvath, T., Docherty, K. S., Worsnop, D. R., and Jimenez, J. L.: Field-deployable, high-resolution, time-of-flight aerosol mass spectrometer, Anal. Chem., 78, 8281-8289, doi:10.1021/ac061249n, 2006.

Eddingsaas, N. C., Loza, C. L., Yee, L. D., Chan, M., Schilling, K. A., Chhabra, P. S., Seinfeld, J. H., and Wennberg, P. O.: $\alpha$ pinene photooxidation under controlled chemical conditions-Part 2: SOA yield and composition in low- and high- $\mathrm{NO}_{\mathrm{x}}$ environments, Atmos. Chem. Phys., 12, 7413-7427, doi:10.5194/acp12-7413-2012, 2012.

Farmer, D. K., Matsunaga, A., Docherty, K. S., Surratt, J. D., Seinfeld, J. H., Ziemann, P. J., and Jimenez, J. L.: Response of an aerosol mass spectrometer to organonitrates and organosulfates and implications for atmospheric chemistry, P. Natl. Acad. Sci USA., 107, 6670-6675, doi:10.1073/pnas.0912340107, 2010.

Francisco, M. A. and Krylowski, J.: Chemistry of organic nitrates: Thermal chemistry of linear and branched organic nitrates, Ind. Eng. Chem. Res., 44, 5439-5446, doi:10.1021/ie049380d, 2005.

Fraser, M. P., Cass, G. R., Simoneit, B. R. T., and Rasmussen, R. A.: Air quality model evaluation data for organics. 4. $\mathrm{C}_{2}-\mathrm{C}_{36}$ nonaromatic hydrocarbons, Environ. Sci. Technol., 31, 2356-2367, doi:10.1021/es960980g, 1997.

Gentner, D. R., Isaacman, G., Worton, D. R., Chan, A. W. H., Dallmann, T. R., Davis, L., Liu, S., Day, D. A., Russell, L. M., Wilson, K. R., Weber, R., Guha, A., Harley, R. A., and Goldstein, A. H.: Elucidating secondary organic aerosol from diesel and gasoline vehicles through detailed characterization of organic carbon emissions, P. Natl. Acad. Sci. USA., 109, 18318-18323, doi:10.1073/pnas.1212272109, 2012.

Hildebrandt, L., Donahue, N. M., and Pandis, S. N.: High formation of secondary organic aerosol from the photo-oxidation of toluene, Atmos. Chem. Phys., 9, 2973-2986, doi:10.5194/acp-92973-2009, 2009.

Jenkin, M. E., Saunders, S. M., Wagner, V., and Pilling, M. J.: Protocol for the development of the Master Chemical Mechanism, MCM v3 (Part B): Tropospheric degradation of aromatic 
volatile organic compounds, Atmos. Chem. Phys., 3, 181-193, doi:10.5194/acp-3-181-2003, 2003.

Jordan, C. E., Ziemann, P. J., Griffin, R. J., Lim, Y. B., Atkinson, R., and Arey, J.: Modeling SOA formation from $\mathrm{OH}$ reactions with $\mathrm{C}_{8}-\mathrm{C}_{17}$ n-alkanes, Atmos. Environ., 42, 8015-8026, doi:10.1016/j.atmosenv.2008.06.017, 2008.

Keywood, M. D., Varutbangkul, V., Bahreini, R., Flagan, R. C., and Seinfeld, J. H.: Secondary organic aerosol formation from the ozonolysis of cycloalkenes and related compounds, Environ. Sci. Technol., 38, 4157-4164, doi:10.1021/es035363o, 2004.

Kroll, J. H., Donahue, N. M., Jimenez, J. L., Kessler, S. H., Canagaratna, M. R., Wilson, K. R., Altieri, K. E., Mazzoleni, L. R., Wozniak, A. S., Bluhm, H., Mysak, E. R., Smith, J. D., Kolb, C. E., and Worsnop, D. R.: Carbon oxidation state as a metric for describing the chemistry of atmospheric organic aerosol, Nat. Chem., 3, 133-139, doi:10.1038/NCHEM.948, 2011.

Kwok, E. S. and Atkinson, R.: Estimation of hydroxyl radical reaction rate constants for gas-phase organic compounds using a structure-reactivity relationship: An update, Atmos. Environ., 29, 1685-1695, doi:10.1016/1352-2310(95)00069-B, 1995.

Lambe, A. T., Onasch, T. B., Croasdale, D. R., Wright, J. P., Martin, A. T., Franklin, J. P., Massoli, P., Kroll, J. H., Canagaratna, M. R., Brune, W. H., Worsnop, D. R., and Davidovits, P.: Transitions from functionalization to fragmentation reactions of laboratory secondary organic aerosol (SOA) generated from the $\mathrm{OH}$ oxidation of alkane precursors, Environ. Sci. Technol., 46, 5430-5437, doi:10.1021/es300274t, 2012.

Lim, Y. B. and Ziemann, P. J.: Products and mechanism of secondary organic aerosol formation from reactions of $n$-alkanes with $\mathrm{OH}$ radicals in the presence of $\mathrm{NO}_{\mathrm{x}}$, Environ. Sci. Technol., 39, 9229-9236, doi:10.1021/es051447g, 2005.

Lim, Y. B. and Ziemann, P. J.: Chemistry of secondary organic aerosol formation from $\mathrm{OH}$ radical-initiated reactions of linear, branched, and cyclic alkanes in the presence of $\mathrm{NO}_{\mathrm{x}}$, Aerosol Sci. Tech., 43, 604-619, doi:10.1080/02786820902802567, 2009a.

Lim, Y. B. and Ziemann, P. J.: Effects of molecular structure on aerosol yields from $\mathrm{OH}$ radical-initiated reactions of linear, branched, and cyclic alkanes in the presence of $\mathrm{NO}_{\mathrm{x}}$, Environ. Sci. Technol., 43, 2328-2334, doi:10.1021/es803389s, 2009b.

Lim, Y. B. and Ziemann, P. J.: Kinetics of the heterogeneous conversion of 1,4-hydroxycarbonyls to cyclic hemiacetals and dihydrofurans on organic aerosol particles, Phys. Chem. Chem. Phys., 11, 8029-8039, doi:10.1039/B904333K, 2009c.

Loza, C. L., Chhabra, P. S., Yee, L. D., Craven, J. S., Flagan, R. C., and Seinfeld, J. H.: Chemical aging of $m$-xylene secondary organic aerosol: Laboratory chamber study, Atmos. Chem. Phys., 12, 151-167, doi:10.5194/acp-12-151-2012, 2012.

Martin, P., Tuazon, E. C., Aschmann, S. M., Arey, J., and Atkinson, R.: Formation and atmospheric reactions of 4,5dihydro-2-methylfuran, J. Phys. Chem. A, 106, 11492-11501, doi:10.1021/jp021499h, 2002.

Matsunaga, A. and Ziemann, P. J.: Gas-wall partitioning of organic compounds in a Teflon film chamber and potential effects on reaction product and aerosol yield measurements, Aerosol Sci. Tech., 44, 881-892, doi:10.1080/02786826.2010.501044, 2010.

McMurry, P. H. and Rader, D. J.: Aerosol wall losses in electrically charged chambers, Aerosol Sci. Tech., 4, 249-268, doi:10.1080/02786828508959054, 1985.
Molina, L. T., Madronich, S., Gaffney, J. S., Apel, E., de Foy, B., Fast, J., Ferrare, R., Herndon, S., Jimenez, J. L., Lamb, B., Osornio-Vargas, A. R., Russell, P., Schauer, J. J., Stevens, P. S., Volkamer, R., and Zavala, M.: An overview of the MILAGRO 2006 Campaign: Mexico City emissions and their transport and transformation, Atmos. Chem. Phys., 10, 8697-8760, doi:10.5194/acp-10-8697-2010, 2010.

Ng, N. L., Chhabra, P. S., Chan, A. W. H., Surratt, J. D., Kroll, J. H., Kwan, A. J., McCabe, D. C., Wennberg, P. O., Sorooshian, A., Murphy, S. M., Dalleska, N. F., Flagan, R. C., and Seinfeld, J. H.: Effect of $\mathrm{NO}_{\mathrm{x}}$ level on secondary organic aerosol (SOA) formation from the photooxidation of terpenes, Atmos. Chem. Phys., 7, 5159-5174, doi:10.5194/acp-7-5159-2007, 2007a.

Ng, N. L., Kroll, J. H., Chan, A. W. H., Chhabra, P. S., Flagan, R. C., and Seinfeld, J. H.: Secondary organic aerosol formation from $m$-xylene, toluene, and benzene, Atmos. Chem. Phys., 7, 3909-3922, doi:10.5194/acp-7-3909-2007, 2007b.

Perraud, V., Bruns, E. A., Ezell, M. J., Johnson, S. N., Yu, Y., Alexander, M. L., Zelenyuk, A., Imre, D., Chang, W. L., Dabdub, D., Pankow, J. F., and Finlayson-Pitts, B. J.: Nonequilibrium atmospheric secondary organic aerosol formation and growth, P. Natl. Acad. Sci. USA., 109, 2836-2841, doi:10.1073/pnas.1119909109, 2012.

Pierce, J. R., Engelhart, G. J., Hildebrandt, L., Weitkamp, E. A., Pathak, R. K., Donahue, N. M., Robinson, A. L., Adams, P. J., and Pandis, S. N.: Constraining particle evolution from wall losses, coagulation, and condensation-evaporation in smogchamber experiments: Optimal estimation based on size distribution measurements, Aerosol Sci. Tech., 42, 1001-1015, doi:10.1080/02786820802389251, 2008.

Presto, A. A., Miracolo, M. A., Kroll, J. H., Worsnop, D. R., Robinson, A. L., and Donahue, N. M.: Intermediate-volatility organic compounds: A potential source of ambient oxidized organic aerosol, Environ. Sci. Technol., 43, 4744-4749, doi:10.1021/es803219q, 2009.

Presto, A. A., Miracolo, M. A., Donahue, N. M., and Robinson, A. L.: Secondary organic aerosol formation from high- $\mathrm{NO}_{\mathrm{x}}$ photo-oxidation of low volatility precursors: $n$-Alkanes, Environ. Sci. Technol., 44, 2029-2034, doi:10.1021/es903712r, 2010.

Riipinen, I., Pierce, J. R., Yli-Juuti, T., Nieminen, T., Häkkinen, S., Ehn, M., Junninen, H., Lehtipalo, K., Petäjä, T., Slowik, J., Chang, R., Shantz, N. C., Abbatt, J., Leaitch, W., Kerminen, V. M., Worsnop, D. R., Pandis, S. N., Donahue, N. M., and Kulmala, M.: Organic condensation: A vital link connecting aerosol formation to cloud condensation nuclei $(\mathrm{CCN})$ concentration, Atmos. Chem. Phys., 11, 3865-3878, doi:10.5194/acp-11-38652011, 2011.

Rogge, W. F., Hildemann, L. M., Mazurek, M. A., Cass, G. R., and Simoneit, B. R. T.: Sources of fine organic aerosol. 3. Road dust, tire debris, and organometallic brake lining dust: roads as sources and sinks, Environ. Sci. Technol., 27, 1892-1904, doi:10.1021/es00046a019, 1993.

Saunders, S. M., Jenkin, M. E., Derwent, R. G., and Pilling, M. J.: Protocol for the development of the Master Chemical Mechanism, MCM v3 (Part A): Tropospheric degradation of nonaromatic volatile organic compounds, Atmos. Chem. Phys., 3, 161-180, doi:10.5194/acp-3-161-2003, 2003.

Schauer, J. J., Kleeman, M. J., Cass, G. R., and Simoneit, B. R. T.: Measurement of emissions from air pollution 
sources. 2. $\mathrm{C}_{1}$ through $\mathrm{C}_{30}$ organic compounds from medium duty diesel trucks, Environ. Sci. Technol., 33, 1578-1587, doi:10.1021/es980081n, 1999.

Schauer, J. J., Kleeman, M. J., Cass, G. R., and Simoneit, B. R. T.: Measurement of emissions from air pollution sources. 5. $\mathrm{C}_{1}$ $\mathrm{C}_{32}$ organic compounds from gasoline-powered motor vehicles, Environ. Sci. Technol., 36, 1169-1180, doi:10.1021/es0108077, 2002.

Seinfeld, J. H. and Pandis, S. N.: Atmospheric Chemistry and Physics, John Wiley and Sons, Inc., Hoboken, N.J., 2 edn., 2006.

Shilling, J. E., Chen, Q., King, S. M., Rosenoern, T., Kroll, J. H., Worsnop, D. R., DeCarlo, P. F., Aiken, A. C., Sueper, D., Jimenez, J. L., and Martin, S. T.: Loading-dependent elemental composition of $\alpha$-pinene SOA particles, Atmos. Chem. Phys., 9, 771-782, doi:10.5194/acp-9-771-2009, 2009.

Shiraiwa, M. and Seinfeld, J. H.: Equilibration timescale of atmospheric secondary organic aerosol partitioning, Geophys. Res. Lett., 39, L24801, doi:10.1029/2012GL054008, 2012.

Shiraiwa, M., Pfrang, C., Koop, T., and Pöschl, U.: Kinetic multilayer model of gas-particle interactions in aerosols and clouds (KM-GAP): Linking condensation, evaporation and chemical reactions of organics, oxidants and water, Atmos. Chem. Phys., 12, 2777-2794, doi:10.5194/acp-12-2777-2012, 2012.

Shiraiwa, M., Yee, L. D., Schilling, K. A., Loza, C. L., Craven, J. S., Zuend, A., Ziemann, P. J., and Seinfeld, J. H.: Size distribution dynamics reveal particle-phase chemistry in organic aerosol formation, P. Natl. Acad. Sci. USA, 110, 11746-11750, doi:10.1073/pnas.1307501110, 2013.

Song, C., Na, K., and Cocker, D. R.: Impact of the hydrocarbon to $\mathrm{NO}_{\mathrm{x}}$ ratio on secondary organic aerosol formation, Environ. Sci. Technol., 39, 3143-3149, doi:10.1021/es0493244, 2005.

Stephens, S., Madronich, S., Wu, F., Olson, J. B., Ramos, R., Retama, A., and Muñoz, R.: Weekly patterns of México City's surface concentrations of $\mathrm{CO}, \mathrm{NO}_{\mathrm{x}}, \mathrm{PM}_{10}$ and $\mathrm{O}_{3}$ during 19862007, Atmos. Chem. Phys., 8, 5313-5325, doi:10.5194/acp-85313-2008, 2008.
Tkacik, D. S., Presto, A. A., Donahue, N. M., and Robinson, A. L.: Secondary organic aerosol formation from intermediate-volatility organic compounds: Cyclic, linear, and branched alkanes, Environ. Sci. Technol., 46, 8773-8781, doi:10.1021/es301112c, 2012.

Verheggen, B. and Mozurkewich, M.: An inverse modeling procedure to determine particle growth and nucleation rates from measured aerosol size distributions, Atmos. Chem. Phys., 6, 29272942, doi:10.5194/acp-6-2927-2006, 2006.

Volkamer, R., Sheehy, P., Molina, L. T., and Molina, M. J.: Oxidative capacity of the Mexico City atmosphere - Part 1: A radical source perspective, Atmos. Chem. Phys., 10, 6969-6991, doi:10.5194/acp-10-6969-2010, 2010.

Weitkamp, E. A., Sage, A. M., Pierce, J. R., Donahue, N. M., and Robinson, A. L.: Organic aerosol formation from photochemical oxidation of diesel exhaust in a smog chamber, Environ. Sci. Technol., 41, 6969-6975, doi:10.1021/es070193r, 2007.

Yee, L. D., Craven, J. S., Loza, C. L., Schilling, K. A., Ng, N. L., Canagaratna, M. R., Ziemann, P. J., Flagan, R. C., and Seinfeld, J. H.: Secondary organic aerosol formation from low- $\mathrm{NO}_{\mathrm{x}}$ photooxidation of dodecane: Evolution of multigeneration gasphase chemistry and aerosol composition, J. Phys. Chem. A, 116, 6211-6230, doi:10.1021/jp211531h, 2012.

Yee, L. D., Craven, J. S., Loza, C. L., Schilling, K. A., Ng, N. L., Canagaratna, M. R., Ziemann, P. J., Flagan, R. C., and Seinfeld, J. H.: Effect of chemical structure on secondary organic aerosol formation from $\mathrm{C}_{12}$ alkanes, Atmos. Chem. Phys., 13, 1112111140, doi:10.5194/acp-13-11121-2013, 2013. 